\title{
Mugimendu sofistikoaren eta erretorikaren gaien bidez Filosofia Batxilergoan irakasteko hainbat gako ${ }^{1}$
}

\author{
Some clues to teach Philosophy in High School using as themes the Sophistic \\ Movement and Rhetoric
}

\author{
Jonathan Lavilla de Lera* \\ Hezkuntza, Filosofia eta Antropologia Fakultatea UPV/EHU
}

LABURPENA: Ondoko testuak proposamen didaktiko berritzaile bat eskaintzen du. Xede nagusia litzateke agerian uztea mugimendu sofistikoaren eta erretorikaren gaiak Batxilergoko lehen mailako Filosofia ikasgaian txerta daitezkeela, eta hori egitea oso aproposa litzatekela curriculum dekretuak zehazten dituen hainbat helburu eta konpetentzia garatze aldera. Xede horrekin, lehenik eta behin, sarreran, testu honen egitura, motibazioa, status quaestionis-a eta helburu nagusia zehazten dira. Bigarrenik, egungo curriculum dekretuak finkatutako helburu, konpetentzia eta gai nagusiei erreferentzia egiten zaie, gure proposamenaren oinarri teorikoa eta esparrua agerian utziz. Hirugarrenik, mugimendu sofistikoa eta erretorika aurkezten ditugu ikuspegi historiko batetatik, eurekin estuki lotutako hainbat kontzeptu nabarmenduz eta sofistek landu zituzten gai nagusiei sarrera eginez. Laugarrenik, testu honek hainbat ideia eskaintzen ditu mugimendu sofistikoa eta erretorika klasean nola landu ahal den iradokiz eta testu, material eta jarduera jakin batzuen bitartez ikasleen gaitasun erretorikoak nola indar daitezkeen erakutsiz. Azkenik, esandakotik hainbat ondorio ateratzen dira: hautatutako gaien bitartez eta proposatutako jarduera eta metodologiaren bidez, Filosofia ikasgaiari dagozkion hainbat gai, konpetentzia eta eduki zehatz garatzeaz gain, Batxilergo osoan zehar irakasgai guztien elkarrekintzaren bitartez zeharka indartu behar diren zenbait gaitasun landuko lirateke. Gure proposamenaren laguntzaz, posible izan beharko litzateke eskolan garatzeko moduko unitate didaktiko zehatzak sortzea. Hau da, sofistikaren eta erretorikaren gaineko unitate didaktiko zehatzak sortzeko lagungarria izan daitekeen material gisa aurkezten da testu hau.

GAKO-HITZAK: Filosofia, irakaskuntza, bigarren hezkuntza, mugimendu sofistikoa, erretorika.

ABSTRACT: The following text offers an innovative teaching proposal. Its main aim is to show that the issues of sophistic and rhetoric can be introduced in first years' senior high school subject called Philosophy and that doing so is totally convenient in order to develop several scopes and competences determined by the curricular decree. With that goal in our mind, first, in its introduction, this research clarifies which its structure, motivation, state of the art and main aim are. Second, it makes reference to the goals, competences and subjects determined by the current academic decree, so as to show which the theoretical basis and framework of this proposal are. Third, the sophistic movement and rhetoric are introduced from a historical point of view, highlighting some of the concepts related to them and introducing the main themes discussed by them. Fourth, the text offers some ideas concerning how to teach the issue of the sophistic movement and how to strengthen students' rhetorical skills by means of some key texts, material and activities. Finally, the text infers several conclusions; it would be also interesting to point out this among the conclusions: by means of the topics chosen and the activities and methodology proposed, not only would some of the aims, competences and contents related to the subject called Philosophy be developed, but many of the abilities, as well, that must be reinforced in an indirect way by the ensemble of subjects during the whole senior high school.

Through the analysis of all these issues, it should be possible to create some specific educational proposals to be developed in classroom. That is, this work is presented with the scope of being a useful and inspiring material for creating teaching units about sophistic movement and rhetoric.

KEYWORDS: Philosophy, education, senior high school, sophistic movement, Rhetoric.

${ }^{1}$ Nire esker ona Javier Aguirreri testu hau hobetzen laguntzeagatik eta bere laguntasunagatik. Era berean, nire esker ona adierazi nahi nieke EHUko Euskara Zerbitzuko zuzentzaileei eta Tantak aldizkariari lan hau txukuntzen laguntzeagatik.

\footnotetext{
* Harremanetan jartzeko / Corresponding author: Jonathan Lavilla de Lera. UPV/EHU. Balioen Filosofia eta Gizarte Antropologia. Hezkuntza, Filosofia eta Antropologia Fakultatea. Tolosa hiribidea, 70. E-20018 - Donostia/San Sebastián - jonathan.lavilla@ ehu.eus - http://orcid.org/0000-0002-0558-8806
}

Nola aipatu / How to cite: Lavilla de Lera, Jonathan. (2018). «Mugimendu sofistikoaren eta erretorikaren gaien bidez Filosofia Batxilergoan irakasteko hainbat gako"; Tantak, 30(2), 9-39. (https://doi.org/10.1387/tantak.18093).

Jasotze-data: 2017/09/29; Onartze-data: 2018/07/06

ISSN 0214-9753 - elSSN 2444-3581 / (C) 2018 UPV/EHU

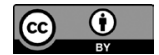

Obra hau Creative Commons Atribución 4.0 Internacional-en lizentziapean dago 


\section{SARRERA}

\subsection{Motibazioa, status quaestionis eta berrikuntza}

Testu honen xede nagusia da proposamen didaktiko berritzaile bat egiteko ideia multzo bat eta materiala eskaintzea, Batxilergoko lehen mailako ikasleei zuzenduta Euskal Autonomia Erkidegoko bigarren hezkuntzako zentroetan aplikagarria den curriculumaren arabera. «Berritzaile» diogunean, batez ere eduki multzoari eta metodologiari erreparatzen diogu. Eskarmentuak erakutsitakoa aintzat harturik, irakasle batzuek esandakoa kontuan hartuta eta hainbat testuliburu behatuta (ik. v. gr. Baigorri, 2015; Cortina, 2008, 2015, Z.Z.E.E. 2009; Z.Z.E.E. 2015), egiaztatu dugu erretorikari garrantzia txikia ematen zaiola eta oso gutxi lantzen dela. Zenbait testuliburutan erretorikaren gaia aipatu, aipatzen da, baina era hagitz arinean eta bere dimentsio historikoari erreparatuz soilik. Alabaina, erretorikaren afera bereziki esanguratsua eta egokia izan liteke curriculumak $^{2}$ zehazten dituen hainbat helburu eta gaitasun irakatsi eta ikasteko. Izan ere, testu honek aldarrikatzen du, erretorikaren ikaspenari esker, ezagutza historikoez gain, gaur egun premiazkoak diren hainbat gaitasun lantzen direla.

127/2016 Dekretuaren arabera, Filosofia deritzon ikasgaiak berebiziko garrantzia eskaini beharko lioke hizkuntza-komunikazioari. Halaber, ikasgai horren bidez pentsamendua era egokian erabiltzeko gaitasuna irakatsi beharko litzateke eta, hortaz, uler daiteke hizkuntzarekin gauza bera aurreikusten dela. Hau da, argudioak era zuzen eta zorrotzean eraikitzeko gaitasuna bultzatu beharko litzateke. Hain zuzen ere, filosofiak argudiatzearekin lotura zuzena eta hautsiezina duen heinean, filosofian jardutea argudioak aztertu, ulertu eta horiei kritika bat egin eta haiekin beste argudioen bidez eztabaida egiteko gaitasunarekin lotzen da.

Hori horrela, defendatzen dugu erretorika jorratzen duen unitate didaktiko baten bidez aukera dagoela aipatu berri ditugun gaitasunak lantzeko. Erretorika, hein handi batean, argudiatzeko teknika gisa jaio zen Grezian, K.a. $v$ mendean ${ }^{3}$. Joera horren eraginpean lerratzen diren autoreek hiz-

2 Aurrerantzean, curriculuma edo dekretua aipatzen dugun aldiro, kontuan eduki erreferentzia moduan Heziberri 2020 planaren honako dokumentuak darabiltzagula: 127/2016 Dekretua, irailaren 6koa, Batxilergoko curriculuma zehaztu eta Euskal Autonomia Erkidegoan ezartzekoa eta 127/2016eko Dekretuaren II. Eranskina osatzen duen curriculum orientatzailea.

${ }^{3}$ Horrekin ez da esan nahi garai horren aurretik erretorika existitzen ez zenik. Aitzitik, erretorikak, hizkuntzaren eta argudiatzearen lanketatzat jotzen badugu, argi dago ia hizkuntza bezain zaharra behar duela izan. Izan ere, ez dago ukatzerik, adibidez, Homero, Hesiodo eta beste autore batzuen lanetan lan erretoriko nabarmena dagoela (Cole, 1991). Edonola ere, argudiatzearen teknika era sistematikoan lantzen hasi zen jakintza sistematikoa, antza, eta hori «erretore» eta «sofista» izenez ezagutzen ditugun autoreekin lotzen da, aipatu berri dugun garaitik aurrera. 
kuntzaren baliabideen azterketa zorrotz eta sistematikoa egiten dute lehen aldiz. Aurrendariak izan ziren gramatika saioak eta testuen lehen iruzkin kritikoak, hain zuzen, garai hartan sortu ziren. Esan daiteke teknika hori garatu zutenak hizkuntzan trebeak (deinoì légein, literalki «hizkuntzan ikaragarriak») zirela. Hortaz, lógos-ean, hots, pentsamenduan baina baita hizkuntzan, maisuak izan zirenen eredua aztertzea baliotsua izan daiteke, ikasleak jabe daitezen hizkuntzaren gaineko trebetasunak duen garrantzia sozio-politiko apartaz. Are gehiago, sofisten testuak eredu moduan hartuta, ikasleek abilezia horiek berdintzeko aukera dute eta, ez hori bakarrik, horien ereduekin lehia eginez, aipatutako konpetentzia landu eta praktikatzeko aukera egokia izan dezakete.

\subsection{Helburua eta egitura}

Testu honen helburuak hurrengoak dira: erretoreen ${ }^{4}$ eta sofisten inguruko aurkezpen historiko baten bitartez, haien garrantzia historikoa azpimarratzea, autore batzuk aurkeztea eta, horrekin batera, testu hautatu batzuk eskaintzea, zeinen bidez material didaktiko oparo eta egokia sortu baitaiteke curriculumak zehazten dituen hainbat gaitasun eta helburu erdiesteko. Hortaz, ez da unitate didaktiko bat aurkeztuko, baizik eta unitate didaktiko bat prestatzeko baliozkoa den informazioen, gaien eta ideien multzoa.

Xede horrekin, lehenik eta behin, curriculumaren hainbat elementu nabarmendu eta azpimarratuko dira, gure proposamenaren oinarri teorikoa eta esparrua zein diren zehaztearren. Lan honen bigarren atalean, berriz, «mugimendu sofistiko» ${ }^{5}$ izenez ezagutzen den joeraren inguruko informazio historiko nagusia eskainiko da. Hirugarren atalean, bestalde, hainbat arazo filosofiko azpimarratuko dira, bigarren atalean emandako azalpenetatik abiatuta, beti ere curriculumaren helburuak eta gaitasunak asetzeko moduko gaiak direla nabarmentzearren. Horrekin batera, azkeneko atalean hainbat testuren erreferentziak eskainiko dira, eta, horrez gain, testu horien

${ }^{4}$ Euskara jatorrean «erretore» hitzak parroko edo herriko elizaren buruari egiten dio erreferentzia. Testu honetan, aldiz, grekerazko rhétor berbaren ordaina da. Usu termino grekoa itzultzeko erabili izan den euskal hitza «hizlari» dugu. Aukera hori ez da erabat okerra, izan ere, rhétor hitzaren adieretako bat hizlaria dugu; edonola ere, ezin dezakegu esan itzulpena guztiz egokia denik, erretorika irakasten duen pertsonari ere erreferentzia egiten baitio. Hain zuzen ere, euskaraz «hizlari» esaten dugunean, batez ere hitzaldia ematen duen pertsona edo jendaurrean hitz egiten duen pertsona datorkigu burura; ez, ordea, elokuentzia irakasten duena. Testu honen kasuan, funtsezkoa da gogoan izatea rhétor $r$ hitzez ezagutzen zen pertsona mintzalari trebea izateaz gain, erretorika-irakaslea ere izan zitekeela. Gauzak horrela, kontu honi dagokionez euskara jatorrari bizkarra eman diogu, termino grekoa modurik literalenean itzuliz, nahiz eta horrek hainbat arazo sor ditzakeela jakin.

${ }^{5}$ Esamoldea Kerferden (1981) lanetik hartu dugu, zeinak arrakasta itzela izan baitu. 
bitartez zer nolako gaiak eta konpetentziak jorratu ahal diren zehaztuko da; era berean, horretarako aproposak izan daitezkeen ariketa batzuk iradokiko dira. Horiek horrela, material didaktikoa sortzeko informazioa eta baliabideak artikuluaren hirugarren eta laugarren ataletan eskainiko dira. Hirugarren atala teorikoagoa izanik, interesa duen irakasleak bertan izango ditu eskuragarri gaiaren nondik norako nagusiak. Hain zuzen ere, horregatik dugu hirugarren atala testuko zatirik luzeena. Laugarren atalean, berriz, aipatutako materialari heltzeko hainbat gako eskainiko dira, modu eskematikoan eta laburrean. Helburua da irakasleek euren kabuz unitateak pentsatzea eta sortzea baina gure lanak ez dezala haiena gehiegi baldintzatu. Izan ere, edukien aldetik zein metodologiari dagokionez, oso unitate didaktiko ezberdinak sor daitezke lan honetan eskainiko diren informazio eta baliabideak abiapuntu harturik.

\section{CURRICULUMAZ ETA BERTAN GAITASUN DISKURTSIBOAK DUEN GARRANTZIAZ}

\subsection{Batxilergoko curriculuma eta diskurtsibitatea}

Curriculum dekretuak lau helburu orokor finkatzen ditu Batxilergoaren xede nagusitzat:

«a) Kulturaren elementuak eskuratzen sakontzea, dimentsio guztiak orekatuta, euskaldunetik unibertsalera.

b) Ikasitakoa erabiltzea, modu kontzientean eta integratuan, bizitzaren arlo guztietako egoerak eta problemak konpontzeko eta hobetzeko aukera berriak sortuz, pertsona maila guztietan garatu ahal izan dadin.

c) Ikasleak helduarorako eta bizitza oso baterako prestatzea, gizabanako diren aldetik; bizikidetza harmoniatsua garatzearekin eta gizarte justu eta zuzenago bat eraikitzearekin konprometituak eta natura zaintzearekin eta garapen jasangarriarekin konprometituak.

d) Goragoko ikasketak egiteko nahiz lanean hasteko prestatzea, berme osoz, eta bizitzan zehar etengabe ikasteko eta prestatzeko motibatzea.» (127/2016 Dekretua, 9 orr.)

Gauzak horrela, esan daiteke curriculum dekretuak berebiziko garrantzia ematen diola diskurtsibitatearen lanketari Batxilergoan; izan ere, helburu horien guztien ardatz dira pentsamendua eta hizkuntza. Txikitatik hasten du gizabanakoak enkulturizazio-prozesua. Prozesu horretan, gure kultura zehatzeko herritar batek - baina baita munduko ezein herritarrak ere - kultura horretan jarraitu behar dituen gutxieneko patroiak barneratzen ditu. Nahiz eta prozesua ez den soilik hizkuntzaren bidezkoa, begien bistakoa da informazio jario horren zati handi bat — funtsean, handiena- 
hizkuntzaren bidez jasotzen dela, bai ahozkoan bai idatzizkoan. Hain zuzen ere, enkulturizazioaren gako-elementuetako bat hizkuntzaren ikaskuntza da, hezkuntza formalaren bitarteko nagusia hizkuntza baita. Pertsona baten garapen osoa erdiestea bere gaitasun logiko-diskurtsiboa bere maila gorenera eramatearekin estuki loturik dago. Giza heldutasuna, preseski, horrekin erlazionatu ohi da; izan ere, gizartean pertsona heldu eta aktibo moduan txertatzeak - hau da, dagozkion eskubide eta betebeharrak aintzat harturik - horixe eskatzen baitu, hein handi batean bederen. Gizartean era egokian txertatzeak eta bertan parte-hartzeak besteekin harremanean egotea esan nahi du. Harreman horietan hizkuntzaren garrantzia ukaezina da, gizartea harmoniatsu bat osatzea, besteak beste, elkarrekintzan sortzen diren arazoak eztabaidatu eta akordioak lortzean datza eta. Hori, jakina, hizkuntzaren bidez egiten da. Horretaz gain, aipatzekoa da hizkuntzaren eta pentsamenduaren lanketari esker, gure ikas-prozesuak aurrera darraiela eta indartu ere egiten dela. Besteak beste, hizkuntza era egokian menperatzeak goragoko ikasketak egitea eta lan munduan ongi txertatzea posible egiten du, bai hezkuntza formalaren bidetik - goi mailako ikasketak barne - eta bai hezkuntza ez-formalaren bidetik ere. Laburbilduz, esan genezake Batxilergoaren xede nagusietako bat ikasleriaren ahalmen diskurtsiboa garatzea izango litzatekeela, curriculumean hori zeharka baino adierazten ez bada ere.

Diskurtsoaren eta pentsamendu logikoaren garrantzia ere begien bistakoa da Batxilergoko dekretuak zehazten dituen oinarrizko bost zehar-konpetentzietan: «1) hitzez, hitzik gabe eta modu digitalean komunikatzeko konpetentzia; 2) ikasten eta pentsatzen ikasteko konpetentzia; 3) elkarbizitzarako konpetentzia; 4) ekimenerako eta ekiteko espiriturako konpetentzia; 5) izaten ikasteko konpetentzia» (127/2016 Dekretua, 10-11 orr.).

Esan den moduan, komunikazioa, hein handi batean, hizkuntzaren bidez bideratzen da; hortaz, zenbat eta hizkuntza-konpetentzia jasoagoa eduki, orduan eta lanabes oparoagoak izango ditu ikasleak era eraginkorrean komunikatzeko. Ikasi eta pentsatu, oro har, biak era diskurtsiboan egiten ditugu, eta horrela komunikatzen gara gizartean ere. Hain zuzen, elkarrekin bizitzen ikasteak lotura estua du elkarrizketan aritzen ikastearekin, jarduera dialogikoetan premiazkoa baita ikuspuntu ezberdinak dituzten pertsonak ados jartzeko bideak bilatzen jakitea. Gizartean elkarbizitza egokia edukitzeko, gizabanako bakoitzak erantzukizunez jokatzen ikasi behar du. Erantzukizunez bizitzea nork bere erabaki eta ekintzen berri eman eta justifikatzeko gaitasunean datza eta hori, noski, hizkuntzaren baliabideen bitartez egin ohi da. Ekimenerako eta ekiteko espiriturako konpetentziak ere lotura estua du horrekin, izan ere, ekimenak pentsamendu diskurtsiboarekin planifikatzeaz gain, hizkuntza erabiltzen da nagusiki besteei azaldu, partekatu, abian jarri eta saltzeko ere. Era berean, esan genezake izaten ikastea pertsona gisa garatzean eta suertatzen diren arazoei aurre egitean datzala. Pertsona moduan garatzeak lotura estua du era autonomoan baina komuni- 
tate barruan bizitzeko gaitasuna erdiestearekin, hau da, erantzukizunez eta akordioen bitartez konpontzeko gaitasunarekin. Kontuan harturik akordio horiek elkarrizketa aktiboaren bidez eraikitzen direla eta nork bere posizio eta ikuspegia diskurtsoaren bidez defendatu eta aldarrikatzen dituela, argi dago Batxilergoaren dekretuak aurreikusitakoaren arabera, sustatu egin beharko litzatekeela ikasleriaren ahalmen diskurtsiboa.

Horiek horrela, agerikoa da garrantzi berezia duela gaitasun diskurtsiboen lanketak Batxilergoan. Dena den, norbaitek gai horretan sakondu nahi izatekotan, Batxilergoko dekretuan jasotako oinarrizko bost zehar-konpetentzien osagaiei erreparatzea du (ik. 127/2016ko Dekretuaren II. eranskinean jasotako curriculum orientatzailea, 21-23 orr.). Osagaiok agerian uzten dute hizkuntza menperatzeak duen garrantzia, izan ere, konpetentzia horietan guztietan nabarmentzen da hizkuntzaren bidez egiten diren edo hizkuntza erabiltzearekin loturik dauden ekintzak. Gauzak horrela, hein handian Batxilergoak pentsamendu logikoa eta hizkuntza-abilezia garatzea sustatzen du eta, hortaz, ikasgai guztiek, neurri jakinean, helburu horretara bideratu beharko lukete ikaslea. Alabaina, jakina da ikasgai bakoitzaren berezkotasuna dela-eta, zenbait ikasgaik beste batzuek baino aukera handiagoa eskaintzen dutela modu espezifikoan gaitasun horiek landu eta garatzeko. Horrela bada, jarraian curriculum dekretuak Batxilergoko lehen mailako Filosofia ikasgairako zehazten dituen hainbat helburu eta gaitasun nabarmenduko ditugu, ikasgai horretan aipatu berri ditugun trebetasunak lantzea funtsezkoa dela agerian uzteko.

\subsection{Filosofia eta diskurtsibitatea}

Funtsean, esan genezake filosofiak pentsamendu-forma zehatz batekin duela lotura. Filosofian aritzea, hein handi batean, azterketa-lana egitean datza; hots, gizartearen, norbanakoaren edo testuen etsamina kritikoa egitea da funtsean filosofia. Hausnarketa hori pentsamendu diskurtsiboaren bidez gauzatzen da, oro har, nahiz eta zenbait formaren bidez adierazi, besteak beste, barne-gogoetaren eta ahoz zein idatzizko perpausen bidez. Erabiltzen duen baliabide nagusia argudiatzea da: errealitatea argudiatzearen bidez azaltzen saiatzen da eta errealitate hori eraldatu eta hobetzeko proposamenak ere argudiatzearen bidez osatzen ditu filosofiak. Filosofia lantzeak konpetentzia diskurtsiboa garatzearekin zerikusi estua duenez, ikasgaiaren edukiek eta metodologiak horretara bideratu behar dute ikaslea. Izan ere, curriculumak argi uzten duenez, filosofian berebiziko garrantzia dute eredu historikoek. Filosofian aurrekoen pentsamenduaren azterketak garrantzia itzela du, bai abiapuntu moduan eta baita dialogoa eraikitzeko elementu lez ere. Gaur egungo testuinguruan, ikaslea hezi nahi da era autonomoan pentsatu, argudiatu eta erabakitzeko gai izan dadin, baina horretarako, eredu batzuk kontuan hartzea komeni da. 
Kontuan harturik 1.1 puntuan aipatu ditugun konpetentziak Batxilergoko ikasgai guztien bidez eskuratu behar direla, argi dago Filosofia ikasgaiak ere hori sustatu behar duela. Are gehiago, Filosofian pentsamendua, argudiatzea eta elkarrizketa lantzen diren heinean, argi dago ikasgaiak berebiziko garrantzia izan beharko lukeela lehenago azpimarratu dugun ahalmen diskurtsiboa garatzen laguntzeko. Kontu hori oso agerikoa da ikasgaiaren helburu zehatzak aztertuz gero. Hain zuzen ere, horietan guztietan arrazoibide edo argudiaketa diskurtsiboarekin lotzen diren gaitasun edo jarduerez hitz egiten da. Hona hemen zortzi helburu horiek:

«1. Gaur egungo gizarteaz eta hura aldatzeko beharraz gogoeta egitea, eta horretan, datu adierazgarriak biltzea eta aztertzea, lekuan lekuko gertaerak «irakurri» ahal izateko beharrezkoa den oinarrizko interpretazio pertsonala egituratzeko; Euskal Herrian norberarengandik gertuen gertatzen direnak, batez ere.

2. Norberaren ingurua transformatzeko prozesuak proposatzea, eta horretan, sormena eta konpromiso pertsonala oinarri hartzea, gutako bakoitza aldaketa sozialaren alde urratsak egin ditzakeen eragile potentziala dela ulertzeko.

3. Testu filosofikoen barne-koherentzia eta testuinguru historikoa aztertzea, eta horretan, testuok aurkeztutako arazoak eta emandako argudio nahiz konponbideak identifikatzea, norberaren ekarpen pertsonalak ere barnean hartzen dituzten iruzkin kritikoak egiteko.

4. Ekoizpen sinboliko adierazgarrienen bidez norberaren ingurunearen alderdi sinboliko-komunikatiboa ikertzea eta aztertzea, Euskal Herriko esparru soziokulturala modu teoriko-praktikoan ezagutzeko eta, horrela, errealitatea ulertzeko interpretazio-gakoak eskuratzeko.

5. Filosofiaren berariazko baliabideetan oinarrituta, eguneroko gertaerei ikuspegi kritiko-erreflexibo batetik aurre egiteko baliabide intelektual eta epistemologikoak eskuratzea.

6. Norberaren ideien alde bai ahoz eta bai idatziz argudiatzea, eta horretan, norberaren ideiak eta argudioak besteenekin kontrastatzea, diskurtso pertsonal koherenteak josteko.

7. Elkarrizketa filosofikoan trebatzea, eta hori geureez bestelako ikuskerekin modu arrazionalean bat egiteko bidetzat hartzea, haren bidez errealitateari buruzko norberaren ikuspegia eraikitzeko.

8. Lan intelektual autonomorako oinarrizkoak diren prozedurak erabiltzea: informazioa bilatzea eta aukeratzea, idatzizko iturrien eta iturri digitalen (Internet) bidez; lortutako informazioa kontrastatzea, aztertzea, sintetizatzea eta ebaluatzea, arazoak zorrotz aurkeztea ezaugarri duten eztabaida arrazionalen bidez; eta informazio hori guztia jarduera filosofikoetan eta jarduerokin lotutako ekoizpenetan erabiltzea.» (127/2016 Dekretua, 219-220 orr.) 
Filosofia ikasgairako finkatutako helburuek hizkuntzarekin eta pentsamendu diskurtsiboarekin lotura estua dute. Filosofian pentsamenduari kritikotasuna eskatzen zaion heinean, pentsamenduaren gaineko pentsamendua eraikitzeko gaitasuna lantzen da; hau da, pentsamenduaren produktu diren ahozko edo idatzizko arrazoibideak epaitzeko gaitasuna bereganatzea. Beste era batera esanda, ikasgai horren muina diskurtsibitatearekin lotzen da. Izan ere, filosofiako helburuak erdiesteak gogoeta modu zuzen eta kritikoan egitea, solaskideekin hitz egitea eta argudiatzea eskatzen du. Hortaz, ikasgaiak ikaslea hizkuntza eta hizkuntzaren logika garatzera bideratu behar du.

Funtsean, filosofian jarduteak pentsamendu diskurtsiboa era jakin batean erabili eta adieraztea eskatzen du. Irakasgai horretan diskurtsoaren hainbat aspektu lantzen dira eta, are gehiago, elkarrizketa edo dialogoa sustatzen da. Herritar gisa pentsatu eta hitz egiteak, hein handi batean bederen, komunitate jakin baten testuinguruan pentsatu eta komunitate horretako beste ikuspegiekin dialogatzea esan nahi du, eta, horrekin batera, auzien inguruan ados jartzea. Komunitate jakin batean diskurtso indibidual solipsistek ez dute zentzu handirik, izan ere, erabakiak akordioen bidez eratzen dira eta akordioak dialogoaren bidez eraikitzen dira. Horregatik, ikasgai honek ekarpen esangarria egiten dio gaitasun dialogikoaren garapenari.

\subsection{Diskurtsibitatearen garrantziaz}

Batxilergoan, Filosofia ikasgaiak pentsatzeko gaitasuna landu beharko luke. Horretarako, besteak beste, ikasleak ikasi beharko luke argudio mota ezberdinak identifikatzen eta erabiltzen, eta auzi bati ikuspegi ezberdinetatik heltzen. Era berean, pentsamendua beti hizkuntzaren bitartez azaleratzen den heinean, ez litzaioke eskatu behar pentsamenduan soilik treba dadin, eta hizkuntzaren aldetik ere trebatu beharko luke. Pentsamendua diskurtsiboa da hein handi batean bederen; hau da, gure pentsamendua hizkuntzaren bidez mamitu eta azaleratzen da. Horregatik, argudiatzen trebea izateko eta pentsamendua garatzeko hizkuntza gaitasunak landu behar dira, besteak beste.

Hizkuntza erabiltzean, pentsamendu-prozesuetan bezala, arau batzuk jarraitzen ditugu eta norbaitek horiek jarraitzen ez dituenean, bere hizkuntza edo pentsamendua zuzena ez dela diogu. Horrela, bada, Mendebaldean, oro har, pentsatzerakoan - poesian eta beste zenbait hizkuntza modu zehatzetan salbu - logika jakin bat darabilgu. Hots, printzipio logiko batzuk errespetatzen ditugu. Hain zuzen, hirugarrena baztertzearen printzipioa (tertium non datur edo principium tertii exclusi) edo kontraesanik ezaren printzipioa dira gure hizkuntza eta pentsamendua gobernatzen duten oinarrizko arauak. Entsegu batean, epaiketa batean edota biltzar batean, esate baterako, gutxieneko arau horiek jarraitu behar dira eta, hola ez bada, kritika latzak egiten zaizkio betetzen ez dituenari, eta bere diskurtsoa zentzugabetzat jo. Hau da, hizkuntzaren eta pentsamenduaren zuzenta- 
suna logikak neurtzen du hein handi batean. Horregatik, gaitasun diskurtsiboa garatu ahal izateko pentsamenduaren eta hizkuntzaren logika ezagutu beharra dago.

Edonola ere, pentsamendua eta hizkuntza ez dira logika soila. Diskurtso arrunta ez da poesiaren diskurtsoa, baina ezta logika formalarena ere. Beste era batera esanda, hitz egiterakoan gauzak deskribatzeaz gain, desirak, aginduak, nahiak, beldurrak eta bestelakoak azaltzen ditugu. Hau da, pentsamenduak zein hizkuntzak dimentsio logikoaz gain, besteak beste, ondoko alderdiak ditu: komunikaziozkoa, adierazpenekoa, desirazkoa, sinbolikoa, aginduzkoa eta erretorikoa. Nahiz eta gutxieneko logika beti nolabait erabili ohi den, pentsatu eta hitz egitekorakoan darabilgun hizkuntzak egitura sasi-logikoa baino ez du sarri. Are gehiago, egoera askotan helburua ez da logikari jarraituz hitz egitea, hizkuntzaren bitartez helburu bat lortzea baizik. Hortaz, diskurtsoa ezin da bere dimentsio logikoaren ikuspegitik aztertu soilik. Beste alderdi batzuk ere hartu behar dira aintzat diskurtsoa aztertzeko orduan.

Diskurtsibitatea garatzeak hizkuntzaren alderdi ezberdinak kontuan hartzearekin lotura estua du eta hori Batxilergoko etaparako aurreikusita dagoen xede nagusienetako bat den heinean, hizkuntzaren dimentsio bestelakoen inguruan gogoeta egitea ere eskatzen du. Hain zuzen ere, Batxilergoko dekretuak zehazten dituen helburuak eta edukiak kontuan hartuta, $\mathrm{Fi}$ losofia ikasgaiak testuinguru egokia eskaintzen du hori guztia lantzeko eta lortzeko. Curriculumak aditzera ematen du garrantzitsua dela Filosofia irakasgaian Filosofiaren historia aztertzea. Aurreikusten diren edukien artean, besteak beste, honako hauek aipatzen dira: mitotik logosera doan prozesua, mendebaldeko filosofiaren sorrera Grezian, erlatibismoa (Egia edo egiak?), gizakiaren dimentsio soziokulturala, subjektua, ekintza moralaren oinarriak, erlatibismo moral eta botere politikoaren jatorria eta zilegitasuna ${ }^{6}$. Gaiok era ezberdinetan eta autore ezberdinen bidez landu daitezke, jakina. Aukera bat mugimendu sofistikotik abiatuta egitea da. Alabaina, testuliburuetan mugimendu sofistikoaren inguruan ezer gutxi aipatzen den arren,

\footnotetext{
${ }^{6}$ Edukiak ez dira hona ekarri dekretuan hitzez hitz datozen bezala, oro har, oso zabalak direlako eta irakasleak nola zehaztu behar dituen erabakitzeko aukera ematen dutelako. Moldatu diren curriculumeko edukiak ondokoak lirateke: «Filosofia eta jakintza arrazionala. Azalpen aurrearrazionala: mitoa eta magia. Azalpen arrazionala: arrazoi mena eta zentzumenak», «Jakintza filosofikoa historian: mendebaldeko filosofiaren sorrera Grezian, egiarekiko miresmenean eta haren bilaketan oinarritua, naturaren gaineko itaun metafisiko greziarra eta biratze antropologikoa», «Ezagutzaren problema filosofikoa. Egia ala egiak?», «"Gizakia” kontzeptuaren eraikuntza kulturala», «Kultura eta dimentsio sinbolikoa. Komunikazioa, artea eta hizkuntzak», «Sozializazio-prozesuak "bigarren modernitatean": indibiduazioa eta haren mekanismoak», «Giza eskubideak, legezkotasuna eta giza gatazka elkarrizketaren bidez eraldatzea (akordioa, bitartekaritza, negoziazioa), eta lankidetza», «Arrazoimen praktikoa: etika eta filosofia politikoa» (ik. 127/2016eko Dekretuaren II. Eranskina osatzen duen curriculum orientatzailea, 440-442, orr.).
} 
izen horrekin ezagutu den mugimendua aztertzeak abagune egokia sortzen du irakasgairako aurreikusitako konpetentziak garatu eta oraintsu aipatu diren edukiak lantzeko.

Hori horrela, hurrengo atalean Grezian erretorika era autonomoan lantzen hasi zen garaiaz mintzatuko gara, eta aipatu berri ditugun edukiak testuinguru historiko horren lanketaren bidez jorratu ahal direla nabarmenduko da. Gainera, azpimarratuko da sofista eta erretoreek hizkuntzarekin eta hizkuntzaren lanketarekin duten ardura. Horrela, ikasleek berbaren inguruko gogoeta batzuk ikusteko aukera izango dute eta, ez hori bakarrik, sofisten, erretoreen eta berauen eragina izan zuten beste autore batzuen testuak eredutzat hartu ahal izango dituzte, eta imitazioaren bitartez, ikasleek aukera izango dute euren gaitasun diskurtsiboa landu eta hobetzeko ere.

\section{MUGIMENDU SOFISTIKOAREN ETA ERRETORIKOAREN INGURUAN: AURKEZPEN XUME BAT}

\subsection{Nortzuk izan ziren sofistak?}

«Sofista» izenez ezagutzen ditugun autoreak sekula ez ziren eskola edo korronte bateratu eta trinko baten jarraitzaileak izan. Are gehiago, «sofista» izenez ezagututako autoreek askotariko ikuspegi moral, etiko eta politikoak defendatu zituzten ${ }^{7}$. Alabaina, bada berauek talde berean sartzeko aukera ematen duen ezaugarri bat: KA v. mendeko testuinguru politiko berrian, sofistek hiritarrei proposamen didaktiko berritzaile bat egin zieten. Hiri-estatu berriko hiritarren aurrean - eta bereziki Atenaseko hiritarren aurrean-, sofistek garai berrietara egokitutako irakasle gisa aurkezten zuten euren burua eta euren zerbitzuak ordain zitzakeen edozeinentzako lan egiteko gertu azaltzen ziren. Sofistak soldata truke euren irakaspena eskaintzeko prest zeuden profesionalak ziren. Gainera, aipatzekoa da ibiltariak zirela, hots, zerbitzu hori hiriz hiri eskaintzen zuten ${ }^{8}$.

\footnotetext{
7 Aipatzekoa da sophistés hitzaren bitartez Grezian ez zutela soilik guk egun «sofista» izenez ezagutzen ditugun autoreak izendatzen; terminoa, bere erroari leial, jakituria aparta zuten pertsonei erreferentzia egiteko erabil zitekeen. Hala nola, testu batzuetan Homero, Solon eta Pitagoras izen horrekin izendatuak izan ziren. Edonola ere, guk gaur egun «sofista» etiketapean garai zehatz bateko zenbait autore ezagutzen ditugu eta ez Homero, Solon, Pitagoras eta beste jakintsu batzuk. Hortaz, izen hori erabiltzerakoan kontuan izan gaur egun esleitzen zaion adieran darabilgula. «Sofista» hitzaren inguruko azalpen zabalagoa nahi duenak Kerferden (1981, 24-41 orr.) lana irakur dezake.

${ }^{8}$ Bonazzik (2010, 15 orr.) hiru ezaugarri horiek (hots, irakaskuntza, zerbitzuen truke soldata bat eskatzea eta natura ibiltaria) aipatzen ditu guk «mugimendu sofistiko» esamoldeaz izendatzen dugun talde heterogeneo haren ezaugarri komuntzat. Orrialde batzuk aurrerago, Bonazzik (2010, 21 orr.) sofisten inguruko definizio bateratu bat emateko saiakera egiten du. Definizioa zehatza ez izanagatik ere, ideia orokor bat edukitzeko baliagarria da oso.
} 
Sofisten loraldia Guda Mediarren amaiera (KA 479) eta Peloponesoko Gerra (KA 431) hasi aurreko 50 urte inguruko aldian izan zen. Garai hori Delosko konfederazioaren aldia dugu, zeinaren gidaritza Atenasek hartu baitzuen bere gain. Aldi horretan Atenasek loraldi politiko, kultural eta ekonomiko nabarmena izan zuen. Sofistak, hain zuzen ere, garai hartako testuinguru ekonomikoaz baliatu ziren haien zerbitzuak eskaintzeko ordaintzeko prest zeuden hiritarrei. Edonola ere, testuinguru ekonomiko oparoa ez da sofisten loraldiaren kausa bakarra; testuinguru politiko berriak ere zeresan handia izan zuen prozesu horretan. Garai hartan Atenasen eta Greziako beste hainbat hiri-estatutan demokrazia zen indarrean zegoen sistema politikoa. Atenaseko hiritarren demokraziaren konstituzioaren oinarri nagusietako bat hiritar guztien berdintasun politikoa zen (isonomía). Horrek esan nahi du hiriaren nondik norakoa hiritarren gehiengoaren nahiaren arabera erabakitzen zela. Erabaki horiek legea (nómos) ezartzen zuten. Ezarritako lege hori erkidea zen guztientzat. Hau da, hiritar guztiek eskubide eta betebehar berberak zituzten legearen aurrean. Era berean, aipatzekoa da horrelako gizarte egitura batean, hitz egiteko askatasunak (isegoría edo parrhesía) berebiziko garrantzia zuela eta, teorikoki behintzat, hiriak eginahalak egin behar zituela hiritarrak modu askean adierazi ahal izan zitezen. Aipatzeko da, halaber, kargu publiko gehienak zozketaren bidez hautatzen zirela. Ausaz hautatutako hiritarrek, hori bai, aurre-epaiketa bat pasa behar zuten eta kargua bete eta gero egindakoa azaldu eta justifikatzeko betebeharra zuten (ik. Solana, 2013, 2-3 orr.).

Testuinguru politiko hartan, hiritar guztiak Asanbladaren kide ziren eta, hori horrela, hiriaren inguruko erabakietan parte-hartzeko eskubidea eta betebeharra zuten. Kontuan izan beharrekoa da sistema politikoa demokrazia parte-hartzailea zela eta ez gaur egungo ordezkaritzaren bidezko demokrazia. Grezia klasikoan, hiritarrek politikan parte hartzeko eskubidea eta betebeharra zuten. Era berean, epaiketetan eta bestelako ekitaldi publikoetan hiritarrek ez zuten salaketa edo defentsa profesional baten esku uzteko aukerarik ${ }^{9}$; hiritar bakoitzak zuzenean parte-hartu behar zuen epaiketan, eta bertan bere posizioa defendatu. Hortaz, bizitza politikoan diskurtsoak (lógos) berebiziko garrantzia zuen, beste hiritarrak limurtzeko, ospea bereganatzeko eta arrakasta edukitzeko tresna nagusienetako bat baitzen (ik. Solana, 2013, 3 orr.).

Hain zuzen ere, testuinguru hartan, sofistek aldarrikatzen zuten hiritarrek zituzten premia sozialak asebeteko zituztela, hots, diskurtsoan trebeak izaten irakatsiko zietela. Sofistek bizitza sozial arrakastatsu bat izate aldera

9 Jakina denez, logogafroen eta bestelako profesionalen zerbitzuak kontratatzeko aukera zegoen hitzaldi bat erosteko. Edonola ere, hiritarrak erositako diskurtsoa buruz ikasteko premia edukitzeaz gain, testuinguruaren arabera moldatu beharko luke. Hortaz, gaitasun diskurtsiboaren eta argudioak sortzeko ahalmenaren garrantzia ukaezina zen. 
aproposa zen hezkuntza eskaintzen zuten, zeina soldata baten truke edonork jaso baitezake.

Sofisten garaian ez zegoen programa didaktiko sistematikorik. Oro har, familia oneko haurrek euren gaitasun fisikoak pedotriba maisuarekin lantzen zituzten, zitara-jolearekin musika ikasten zuten eta gramatiko batekin irakurtzen eta idazten ikasten zuten (ik. Romilly, 1988). Azken horrekin ere poesia tradizionala ikasten zuten, hots, Homero eta Hesiodoren epika. Bi poetak, KA VIII. mendekoak izanagatik aedo eta rapsodei esker artean abestuak zirenak, KA v. mendean oraindik ere Grezia osoko bi hezitzaile nagusitzat jotzen zituzten Greziarrek. Familia oneko haurrek aipatu berri dugun gutxieneko prestakuntza jaso ohi zuten; horren ostean hiritar bakoitzak teknika edo gaitasun zehatz batzuk lantzen zituen, ofizio edo hiriko rol zehatz bat betetzearren. Horrela, batzuek batez ere gorputza lantzen zuten eta beste batzuek, aldiz, gogamenaren eta oroimenaren moduko ahalmenak. Aipatzekoa da artisau gremioek zuten garrantzia, eta gremio horietan ohitura zela maisu-dizipulu segida bat egotea. Halako heziketa-segida ez bide zen arrunta esparru intelektualean. Halaber, garai horretan zegoeneko existitzen ziren sekta edo talde filosofiko txiki batzuen proposamenak - hots, orfismoa eta pitagorismoa - , eta prestakuntza intelektual sistematiko edo osoa eskaintzen zuten. Dena den, sekta horien irakasbidea salbuespena zen, oso txikiak izateaz gain, izaera pribatua baitzuten.

Sofistek eskema berritzaile bat eskaintzen zuten, eta aipatu berri den molde tradizionalarekin hautsi zuten. Esan ohi da hautazko bigarren hezkuntza moduko bat eskaintzen zutela, dagoeneko pedotriba maisu, zitara-jole eta gramatikoaren ikasketak barneratuak zituzten pertsonei, euren adina kontuan hartu gabe. Sofistek erakusleihoan ipintzen zutena hiritar arrakastatsua izatea bermatzen zuen ezagutza-multzoaren transmisioa zen. Dagoeneko KA V. mendeko testuinguruan, Homero eta Hesiodoren poemak ez omen ziren erabilgarriak hiritar arrakastatsua izateko. Izan ere, euren heroien mundua eta garai klasikoaren demokraziaren egitura eta arauak erabat bestelakoak ziren. Hortaz, hezitzaile berri batzuen premia zuen hiriak, sofistek hiritar berriek behar dituzten gaitasunak irakasteko gai zirela defendatzen zuten, soldata arrazoizko baten truke. Sofisten irakaskuntzak helburutzat zuen ikaslea hizkuntzan trebea bilakatzea, horrek bermatzen ziolako arrakasta. Hortaz, sofisten irakaspena arrazional-diskurtsiboa zen hein handi batean, bestela esanda, intelektuala, filosofoena bezalakoa. Alabaina, azken horien irakaspena teorikoagoa zen eta, batez ere, mantsoago eskuratzen zen (Platon, Fedro, 247a, 269c3, 272b5-6; Platon, Politeia, 504b, 621d). Sofistek, aldiz, ikaskuntza prozesu azkarra eskaintzen zuten, eta denbora laburrean hirian arrakasta izatea bermatzen zutela aldarrikatzen zuten (Aristofanes, Hodeiak).

Hirian arrakasta diskurtsoaren bidez lor zitekeela kontuan hartuz gero, azkar ulertzen da sofistek hizkuntzari eskaini zioten arreta. Era sistematikoan landu zituzten hizkuntza eta diskurtsoaren inguruko gaiak, beti ere hizkuntzak sistema demokratiko parte-hartzailean duen garrantzia kontuan 
harturik. Horregatik, gaitasun diskurtsiboa irakasten saiatu ziren. Sofistek besteak limurtzeko gaitasuna eta norberaren tesiak defendatzeko ahalmena irakasten zuten, hots, besteak beste, erretorika maisuak ziren.

Euren proposamen didaktikoa hain izan zen garaikidea eta erakargarria, ezen berebiziko arrakasta eta eragina izan baitzuen. De Romillyren (1988) arabera, KA V. mendeko autore edo pentsalarien artean bat bera ere ez zen egon haien eraginik jaso ez zuenik. Zenbaitek sofisten metodoen ildoa jarraitzen zuten, beste batzuek, aldiz, haien ekimena gogorki maiseatu zuten. Sofisten eskaintzak iraultza moduko bat ekarri zuen hezkuntza tradizionalera ${ }^{10}$. Tradizionalki, hiritar gazteek musu-truk jasotzen zuten heziketa, hiritar nagusiago eta eredugarriengandik ikaspenak jasoz, bai euren bizi-eredua ikusiz eta imitatuz, bai haiekin izandako eztabaiden eta berriketen bidez. Antzinako gizarte-egitura aristokratikoan hiritarrek prestakuntza elkarrengandik eta elkarrekin jasotzen zuten, batak bestearekin zituzten harremanei eta eztabaidei esker, eta eskarmentuaren eta denboraren poderioz. Aitzitik, sofistek eskaintzen zuten arrakasta politikoa edukitzeko behar ziren gaitasunak era zuzen, tekniko, azkar eta ordainpekoan irakastea. Euren eskaintzak, jakina, gazte ugari erakarri zituen, zeinek gogotsu eta itxaropenez beterik kontratatu baitzituzten.

\subsection{Erretorikaren sorreraren inguruko kondaira bat}

Sofistak erretorika-maisuak izan ziren. Hortaz, komeni da erretorika zertan datzan argitzea. Kondaira baten arabera, erretorikaren hastapena KA v. mendean gertatu zen, Sirakusan (Magna Grezian), esparru forentsearekin erlazio estuan, hau da, foro (i.e. agorá greziarra) edo plaza publikoan, eta, beraz, prozesu judizial edo politikoen testuinguruan ${ }^{11}$. Ele horren ara-

10 Sofisten proposamen didaktiko berritzaileak suposatzen zuen iraultzaren gainean Marrou (1965, 104 orr.) horrela mintzatu zen: «Il n'est pas trop fort de parler d'une révolution accomplie par les sophistes dans le domaine de l'éducation grecque».

${ }_{11}$ Cole (1991) irakasleak agerian utzi duenez, era zabal batean ulertuta behintzat, erretorika ez zen ez aipatutako mendean jaio ezta sofistekin ere ez. Are gehiago, hizkuntzak beti izaera erretorikoa duela aitortu beharra dago. Komunikazioan pertsuasioak edo limurtzeak berebiziko garrantzia du eta, sarri, horren arabera eratzen dira hitzaldiak. Beraz, komunikazioaren elementu garrantzitsu bat hizkuntzaren estiloa edo itxura bera dugu. Hau da, darabilgun hizkuntza egoeraren arabera eta entzuleriarengan sortu nahi den efektuaren arabera moldatzen dugu, edertuz edo soilduz, erregistroa jasoz edo apalduz. Hori, adibidez, Homero eta Hesiodoren lanetan begien bistakoa da. Poetak hizkuntza edertu egiten du metrika, errima eta hizkuntzaren beste baliabide batzuen medioz. Hori, jakina, erretorikaren agerbide gisa uler daiteke. Poetak entzulegoarengan lilura sortu nahi du, zentzu batean, limurtze-modutzat kontsideratu daitekeena. Hori esanda, kontuan hartu beharra dago afera horien inguruko pentsamendu eta gogoeta sistematikoa sofistekin jaio zela eta, horregatik, gure testuak erretorikaz mintzatzerakoan sofisten aurreko erretorika - Colek (1991) protoerretorika izendatzen duena - alde batera uzten du. 
bera, Hieron I. eta Gelon tirano populistek pertsona ugari deserritu eta lur ugari konfiskatu zituzten, beste hiritar batzuen artean banatzeko - hots, euren boterearen aldekoak zirenen mesederako-.Tirania amaitutakoan, oso giro nahasia zegoen. Erbesteratutako jendea itzuli zenean, epaiketaprozesu luze eta korapilatsu bat bizi izan zen Sirakusan, zeinean hainbatek deserritu eta haien lurrak galdu izateagatik konpentsazio moduko bat eskatzen baitzuten. Garai horretan, epai-prozesuak fenomeno berria ziren eta epai-mahai herrikoi ugariren premia sortu zen. Epai-prozesuak oso korapilatsuak izan omen ziren. Esaten da sirakusarrak berez elokuenteak zirela, baina ikusita epaitegietan jokoan zutena oso garrantzitsua zela, norbaiti otu bide zitzaion komenigarria zela diskurtsoak nola egin argituko zuen teknika bat sortzea. Antza, testuinguru horretan Korax eta bere ikaslea Tisias izan ziren erretorika tékhne edo ars moduan landu zuten aitzindariak. Koraxek tirania garaian jada hizlari lanak egiten omen zituen, baina aipatu berri ditugun epaiketen testuinguruan, berak bilakatu omen zuen lehen aldiz erretorika arte edo ikasketa sistematiko. Horri esker, auzien aurrean pertsona orok era egokiagoan aldeztu ahal izango zituen bere interesak.

Egiazkoa zein faltsua izan, kondairak bikain azaltzen du testuinguru demokratiko batek zein puntutaraino duen erretorikaren premia. Hori esanda, ikus dezagun era zehatzagoan zertan datzan erretorikaren teknika.

\subsection{Zer da erretorika?}

Antzinaroan eta Erdi Aroan erretorika diskurtsoaren osatze artistikoaz arduratzen zen arte liberala dugu. Bere helburu nagusia limurtzea da eta bere aplikazio praktiko behinena testuinguru judizial eta politikoan egiten da. Hori horrela, erretorikak era egokian hitz egiten irakasten du, beti ere, helburua norbait limurtzea delarik. Komunikazio-teknika horrek «oratoria» izena jasotzen du bere aplikazio praktikoan; hau da, erretorikaren irakaspenak jarraituz trebetasunez mintzatzen den pertsona, hizlari ona dela edo oratorian iaioa dela esan dezakegu. Teknika horren ikaspen teorikoa, berriz, «erretorika» izenez ezagutzen da.

Ars edo tékhne bat hainbat gauza egiteko gaitasun edo abilezia litzateke; gaitasun hori ikaspenaren eta eskarmentuaren bidez eskuratzen da. Argi eduki behar da arte bati dagokionez, bere lorpenak ez direla zoriz edo ustekabean jazoko, baizik eta arrazoibide edo eginbide metodiko bati esker. Arte edo teknika bat menperatzeak arau-segida bat ezagutzea eta praktikan jartzen jakitea eskatzen du; hain zuzen ere horri esker lortzen du teknika ezagutzen duenak zerbait behin eta berriro egin edo sortzeko konpetentzia. Teknika horren arauak jarraitzeak teknika bera hobetzera eramaten gaitu eta arauak jarraituz gero, eta akatsik egin ezean, helburua beti lortu beharko litzateke. Erretorika, bestelako arte liberalen antzera, irakasgaia izan zen. Erretorika modu egokian ikaste aldera, ikas- 
leak berriketan trebea izateko duen gaitasun naturala esanguratsua bada ere, alderdi garrantzitsuena da hitz egiteko arau jakin batzuk ongi ikasi eta menperatzea.

Erdi Aroan, arte liberalak (artes ingenuae) libre jaiotako (ingenus) gizakiaren arteak ziren. Hortaz, garai hartan behintzat, bere irakaspenaren helburu nagusia ez zen etekin ekonomikoa lortzea. Zentzu horretan, arte liberalen eta merkataritza-arteen arteko ezberdintzea zedarritu zitekeen. Erdi Aroan arte liberalak zazpi ziren, eta bi taldetan banatzen ziren: trivium eta quadrivium. Lehen irakaskuntza fasea trivium-ak osatzen zuen eta bertan izpirituaren arteak ikasten ziren, hain zuzen ere, gramatika, erretorika eta dialektika (azken hitz horren bidez gaur egun «logika» izenez ezagutzen dugun jakintzari egiten zitzaion erreferentzia). Quadrivium-a, aldiz, naturaren eta matematiken arteez osatzen zen: aritmetika, musika, geometria eta astronomia.

Erdi Aroko sailkapen horrek erretorikaren natura era aproposean ulertzea errazten du. Gramatika diskurtsoa era zuzenean osatzen irakasten duen zientzia litzateke ( gramatica ars recte loquendi). Erretorika, aldiz, diskurtsoa ongi osatzen irakasten duen teknika (rhetorica ars bene dicendi). Recte eta bene aditzondoen desberdintasunaz ongi jabetzea funtsezkoa da afera ulertzeko: lehenengo kasuan, diskurtsoaren zuzentasunari egiten zaio erreferentzia soilik; bigarrenean, aldiz, diskurtsoaren beraren helburuari egiten zaio erreferentzia; limurtzeari, alegia. Diskurtso erretorikoek hartzailea (entzulea edo irakurlea) bairatzea edo limurtzea dute beti helburutzat eta, hortaz, diskurtsoa ongi osatzea hartzailea limurtu edo liluratzen duen hitzaldia osatzea litzateke. Azkenik, arrazoiketaren legeak eta arrazoiketaren adierazpenen forma aztertzen dituen artea litzateke dialektika edo logika. Besteak beste, silogismo bat ongi sortu den argitzen digun teknika da dialektika; hau da, dedukzio bat formalki logikoa den jakiteko baliagarria den teknika dugu. Dialektikak proposizio batzuetatik baliozkoak edo onargarriak diren beste batzuk deribatzea posible egiten du, baldin eta premisak egiazkoak badira eta inferitzeko modua egokia bada. Silogismoa, jakina, diskurtso limurtzaile mota bat da.

Arrazoiketa logikoak limurtzaileak dira zerbait frogatzen dutelako. Alabaina erretorika-maisuek ederki zekiten gizakiok hitz egiterakoan edo diskurtsoak eraikitzerakoan ez dugula dedukzio logiko zuzen eta zehatzak erabiltzeko ohiturarik. Hau da, bazekiten, oro har, hitz egiteko orduan gizakiok ez dugula frogatzen, argudiatzen baizik. Kasu gehienetan ez dugu hitz egiten unibertsalki onartuak diren premisak oinarri edukita, baizik eta iritzi subjektiboei eutsiz. Hau da, gure komunikazio-esparru ohikoena iritziarena, itxurarena eta usteena dugu. Gainera, kasu gehienetan, hitz egitearen helburu behinena ez da egia zein den zehatz-mehatz jakitea. Esate baterako, epaiketa baten aurrean dauden bi aldeen helburu nagusia ez da egia zein den azaltzea, baizik eta epaileak bairatzea, eurentzat mesedegarriena den ebazpena lortzeko. Horretarako, zientifikoki frogatzea baino - hori 
ezin baita egin kasu askotan - , beste estrategia batzuk erabiltzen dira: hunkitzea, ziurtasuna transmititzea eta abar.

Logikaren eragiketak eta emaitzak zuzenak edo okerrak dira; aitzitik, erretorikaren kasuan, sortutakoa ez da zuzena edo okerra, baizik eta baliozkotasun edo eraginkortasun handiago edo txikiagokoa, limurtze saioaren arrakastaren arabera. Logikan hizkuntza beti modu berean erabiltzen da eta hizkuntza logikoa bera finkoa da. Erretorikaren kasuan, aldiz, berebiziko garrantzia du hizkuntza entzuleriaren arabera doitzeak, helburua berau limurtzea baita. Argudiatzerakoan ez da beharrezkoa arrazoiketaren ziurtasuna erabiltzea; aitzitik, kasuan kasu, eraginkorrenak izango diren tresnak erabili beharko lirateke. Horrela, entimema (enthýmema) oso baliabide erretoriko ohikoa da; baliabide hau ez da silogismoa, nahiz eta silogismo itxura eduki. Demostrazio baten antzekoa den heinean, entimema oso eraginkorra izan daiteke, baina kontuan izan behar da argudiatze-forma bat dela eta ez, haatik, demostrazio eredu bat.

\subsection{Sofisten irakaspen berritzailearen oinarri nagusietako bat: erlatibismo epistemologikoa}

Arestian aipatutakoaren arabera, sofistek, besteak beste, gaitasun diskurtsiboaren bitartez arrakasta politikoa izaten irakasten dute. Gaitasun horrek hiri-estatu demokratikoen testuinguruan berebiziko garrantzia duenez, euren proposamen berritzaileak egundoko arrakasta eduki zuen Atenaseko gazteriaren artean. Horrek, era berean, gizartean eragin soziopolitiko nabarmena izan zuen. Sofistek agerian utzi zuten epaitegietan eta diskurtso politikoetan helburua limurtzea dela. Hori helburu gailena izanik, egiaren gaineko kezka bigarren maila batean geratuko litzateke. Garrantzitsuena diskurtsoaren ahalmen limurtzailea da eta, hortaz, bere egiatasuna baino, bere egiantzekotasunak luke garrantzia; era berean, aproposa edo zentzuzkoa izateak baino, aproposa edo zentzuzkoa emateak luke garrantzia. Egiantzekoa denak ez du zertan egiazkoa izan eta itxura zentzudun edo aproposeko hitzaldiak ez du zertan egiazkoa izan. Hain zuzen ere, sofisten irakaspenak diskurtsoaren itxura zaintzera bideratu zituen ikasleak eta ez, aldiz, bere natura edo egiazkotasuna.

Azken kontu hori adibide klasiko baten bidez irudika daiteke (ik. Platon, Fedro, 273b3-c4). Txikia eta ahula den gizon ausart batek handia eta indartsua den gizon koldar bati jo eta lapurreta egingo balio eta azken horrek lehenengoa epaitegira eramango balu, bietako inor ez litzateke saiatu beharko benetan gertatutakoa azaltzen; komenigarriagoa litzateke egiantzekoa den eta euren interesetara hobekien moldatzen den narrazioa sortzea. Zioa honakoa da: gizon txikiari ez zaio egia esatea komeni, bestela epaia kontra izango baitu. Gizon handiari ere ez zaio egia esatea komeni, beste hiritarren aurrean koldar eta barregarri azalduko litzatekeelako, nahiz 
eta epaiketa irabazi - are gehiago, ez da ziurra egia kontatzekotan epaileek bere narrazioa sinetsiko zutenik-. Hortaz, gizon txikiak esan beharko luke bera txikia izanik eta salaketa ipintzen duena, aldiz, handia, bera ez litzatekeela sekula azken honi jo eta lapurreta egitera ausartuko, batez ere, bere erreakzioaren beldurrez. Gizon txikiak epaileen aurrean erakutsi beharko luke horrelako salaketa bat zentzugabea edo absurdoa dela eta, hortaz, egiantzekoa ez dela. Txikiagoa den horrek argudiatu behar luke bera ez dela hain txoriburua horrelako ekintza bat burutzeko. Aldiz, zuhurra izatekotan, gizon handiak ez luke egia esan behar, hau da, gizon txikia beregana hurbildu zela eta aldez aurretik planifikatu gabe jo eta lapurreta egin ziola. Egia azaltzeak denen aurrean barregarri eta koldar azalduko lukeelako bere burua eta, gainera, ziurra ez delako epaileek bere kontakizuna sinestea. Azkarra balitz, gizon handiak horrelako zerbait esan beharko luke: «gizon txiki batek gizon handi bati jo eta lapurtzea egiantzekoa ez dela jakinik, salatzen dudan gizon txiki honek tresna bat hartu eta niregana hurbilduta, ni ezustekoan nengoela tresnarekin jo eta lapurreta egin dit. Orain, ekintza zital hori inolako ordainik gabe burutu duelakoan dago, pentsaturik bere fisionomia ahulari eta ene gorpuzkera sendoari erreparatuta, inork halako istorioa sinetsiko eta bere planak arrakasta izango duela».

Adibidean ikusten denez, helburu nagusia epaileen aurrean - eta nolabait hiri-estatuan bertan - arrakasta edukitzea da eta, beraz, diskurtsoa horren arabera prestatu eta egokitu beharko luke. Diskurtsoa ez da egiaren errepresentazio huts gisa azaltzen, baizik eta tresna politiko legez ${ }^{12}$. Alabaina, horrek arazo sozial nabarmenak sor zitzakeen. Aristofanes, Platon, Aristoteles eta beste batzuek, hain zuzen ere, ondokoa gogor salatu zuten: diskurtso erretoriko on batek, sofisten arabera, ez luke derrigorrez egiarekin harreman esturik izateko premiarik, egiantzekotasunarekin baizik. Hortaz, hainbat politiko, poeta eta pentsalariren arabera, sofisten irakasgaiak hankaz gora ipintzen zituen printzipio moral eta politikoak; diskurtsoa edozein ekintza edo jarrera zuritzeko eta defendatzeko balio duen gailu izatera pasako litzateke, eta gizartearentzat arrisku nabarmena ekarriko luke.

Afera errotik aztertu nahi bada, kontuan izan beharreko elementua dugu ondokoa: sofistek defendatzen zuten gizakiaren esparrua - eta hortaz diskurtso eta pentsamenduarena ere - iritzi (dóxa) eta usteen mundua dela, eta ez egia ziur eta zalantza-ezinarena. Horrela, lehen aipatutako epaiketaren adibidean, epaileek ez dute egiaren inguruko ziurtasunik eta euren ebazpena defentsak eta akusazioak azaldutakoaren egiantzekotasunaren arabera erabakiko da, hau da, uste edo iritzien bidez. Are gehiago, gizakiok ezagutzen dugun mundua edo objektua beti subjektu baten ikuspe-

12 Cassinek (1995) maisuki azaldu duen moduan, sofistak konturatu ziren lógos-ak ez duela soilik errealitatea errepresentatzeko balio, izan ere, hori egiteaz gain lengoaiak errealitatea sor dezake, eragiten dituen ondorioak direla-eta. Cassinek diskurtsoaren ahalmen horri «l'effet sophistique» esamoldeaz egiten dio erreferentzia. 
gitik ezagutzen da. Ikuspegiak, subjektuak bezainbeste, askotarikoak dira eta, hortaz, objektua edo mundua, guk ezagutzen duguna bederen, subjektiboa dela esan daiteke. Beste era batean esanda: sofistek gizakion ezagutza subjektibo edo erlatiboa dela izan zuten oinarri. Hain zuzen ere, horregatik da hain garrantzitsua erretorikan trebea izatea. Gizakiok gauzak era ziurrean eta erabat objektiboan ezagutuko bagenitu, ezagutza horren arabera hartuko genituzke erabakiak - hots, era tekniko edo zientifikoan - eta ez uste edo iritzi hutsen arabera. Are gehiago, hitzaldiek askotan etorkizuneko erabaki edo hautuak baldintzatzen dituzte eta kasu horietan guztiz agerikoa da hitzaldiek aurreikusten dutena ez dela beti gertatuko denarekin bat etorriko, etorkizuna aurreikusteko dugun gaitasuna mugatua delako. Ziurtasunik ez izanagatik, gizakiok erabakiak hartzeko premia dugu, eta hoberena ematen duen bidea hartu behar dugu. Horregatik, ezagutza ziur gabetanik eta hautuaren ondorioak zehatz-mehatz zeintzuk izango diren jakin gabe, herritarrak hitz egin eta erabakiak hartzeko premia du.

Protagorasen homo-mensura teoria famatuak - zeinaren arabera gizakia gauza guztien neurria den - erlatibismoa aldarrikatzen zuen. Esaldia era anitzetan uler daiteke eta horren esanahiaren interpretazio ezberdinak iradoki dira. Edonola ere, interpretazio ezberdinak puntu batean bat datoz, hots, esaldia erlatibismoaren adierazlea denik ezin daitekeela ukatu. Hain zuzen ere, sofistek erlatibismo epistemologikoa jotzen zuten gizakion ezagutza-markotzat eta horren ondorioa izan zen, alegia, hainbatek erlatibismo morala aldarrikatu izana. Preseski, sofistikaren erlatibismo epistemologikoak baldintzaturik ${ }^{13}$ sortutako erlatibismo moralak bultzatu edo eragin zuen greziar gazte askok tradizio eta unean-uneko legalitatearen aurka egitea. Sofistikaren eragin soziala, hortaz, nabarmena eta garrantzitsua izan zen eta Aristofanes, Platon eta beste hainbat hiritar horren kontra aritu ziren, hots, mugimendu sofistikoaren berrikuntzaren - beste hainbat faktoreren eskutik - ondorioa izan zen ideologia berriaren kontra. Greziako tradizio, moral eta balioak ezbaian ipintzerakoan, jende askok pentsatu zuen herriaren batasuna eta ordena politikoa kolokan zegoela eta, horren kontra egin nahian, sofisten aurkako kritika latzak jaulki zituzten.

Erlatibismo epistemologikoa sofistikaren oinarri eta gakoetako bat zen. Horren arabera, gauzak ikuspegi anitzetatik ezagutzen ditugun heinean eta gure interes eta beharren arabera juzgatzen ditugula kontuan edukirik, ez dago berez ona edo txarra den ezer, ontzat edo txartzat jotzen ditugun gauzak baizik. Hain zuzen ere, gauza bakar baten inguruan diskurtso ezberdinak sor daitezke, eta diskurtso horietan gauza bera lehenengo momentuan onuragarritzat aurkez daiteke eta gero, aldiz, kaltegarritzat. Hau da, gau-

13 Inolaz ere ez genuke esan nahi sofista guztiak - ezta gehienak - erlatibista moralak zirenik. Hala ere, egia da euren erlatibismo epistemologikoarekin limurtuta, erraz pasa daitekeela norbait erlatibismo morala aldarrikatzera. 
zen inguruan ez dago tesi bakar eta dogmatikorik; aitzitik, edozein auzitan posible da kontrajartzen diren bi diskurtso sortzea. Horrek ez dakar kontraesanik, baizik eta ikuspegi kontrajarrien arteko norgehiagoka, i.e. perspektibismoa. Erretorikan maisua izatea, hain justu, askotariko ikuspegiak ikusteko gaitasunarekin lotzen da eta ikuspegi horien aldeko argudioak harilkatzen jakitearekin, testuinguru bakoitzean baliabide komenigarrienak hautatuz.

Hain zuzen ere, sofisten irakasgaia horrekin lotzen zen: diskurtso edo tesi ahula diskurtso edo tesi indartsu bihurtzeko gaitasunarekin. Auzi baten inguruan beti da posible tesi kontrajarriak aurkitzea eta tesi horietako bakoitza defendatzeko moduko argudioak ere aurki daitezke. Gauzak horrela, hitzaldi ahula edo eskasa ematen duena diskurtso indartsu edo limurtzaile gisa aurkezteko gaitasuna duen pertsonak erretorikan maisutasuna du. Beste era batera esanda, diskurtso bikoitzak ${ }^{14}$ sortzeko eta tesi bikoitzak defendatzeko gaitasuna izan beharko lukete erretorika ikasi dutenek.

Erretorika lantzeak, hein handi batean, sormena lantzea suposatzen du, hau da, unean une argudio eta ikuspegi aproposena erabiltzen jakitea. Edonola ere, hori egiteko erretorika-maisuek topoi edo leku-komun batzuen zerrendak zituzten, ikasle guztiek ikasi behar zituztenak eta kontua errazten zutenak. Topiko horiei esker, pertsona batek testuinguru zehatz ezberdinetan zein argudio existitzen ziren eta nola erabil zitezkeen jakingo luke. Hortaz, pertsona batek ez luke zertan asmamen-gaitasun (inuentio) bereziki ona izan beharko; horren ordez, topikoak ongi ikasi eta horiek une egokian (kairós) erabiltzen ikasi beharko luke, eta nahi duen helburua lortzeko bere diskurtsoaren performance-a (actio) ahalik eta hobekien egokitu. Hau da, hitzaldia era ahalik eta era hoberenean ahoskatu beharko luke eta, horretarako, testuinguruaren arabera, patetismoa, ziurtasuna, hizkuntza teknikoa edo bestelako errekurtsoak abian ipini beharko lituzke, bere asmoa betetzeko, hots, limurkorra izateko.

Aipatu den eran, erretorikak teknika izateko asmoa zuen eta, hortaz, bat-batekotasuna ez da bere gakoa, teknika baizik. Hots, erretorika arau eta jakintza batzuen segidan zetzan, eta hizketa-estrategia, kasuan kasu, era komenigarrienean hautatzea eskatzen zuen. Gainera, kontuan eduki behar da teknika horrek erlatibismo epistemologikoa zuela oinarritzat. Gauzak erlatiboak direla aldarrikatzen zen, hots, gauzak orojakilea ez den subjektu baten araberakoak direla. Horrek eta beste faktore batzuek posible egiten dute Grezian anthropozentramendu (ik. Goux, 1999) baten inguruan hitz egitea. Protagorasen homo-mensura teoriak gizakia edo subjektua kokatu zuen erdian, gure sinesmenen, balioen, legeen eta jakintzen sistema sub-

14 Diskurtso bikoitzen eta Dissoì logoí (Laks \& Most, 2016, fr. 41. Diss. = fr. DK90) testuaren inguruan, ik. Conley \& Polansky (1985), Robinson (1979), Rossetti (1980); Solana (1996). 
jektu baten araberakoa dela nabarmenduz. Gure mundua, geurea den heinean, gure neurrian balioztatzen edo neurtzen dugu. Hori dela-eta, giza natura izan zen sofistek landu zuten gai nagusietako bat.

\subsection{Sofistek landutako gai nagusietako batzuk}

Erlatibismo epistemologikoa oinarri edukita, sofista gehienek phýsis/ nómos (natura/konbentzio) dikotomia nabarmendu eta erabili zuten. Alde batetik, badira naturaz - hau da, berez- diren gauzak eta, bestetik, aldiz, konbentzioaren produktu direnak. Naturaren izaeren inguruko gogoetari dagokionez, sofisten artean desadostasun eta ikuspegi ugari zegoen. Edonola ere, esanguratsua da ikustea bi kontzeptu horiek bereizita, sofistek argi uzten zutela naturaz ezarrita ez zegoena konbentzionala zela, hots, gizakiok erabakitako edo sortutako zerbait zela, eta, beraz, beste era batean erabaki edo ezarri ahalko litzateke. Konbentzioa arbitrarioa da, hau da, ez dio lege natural bati men egiten, baizik eta hautu gizatiar edo politiko bati. Horregatik, sofistek greziar gizartearen hainbat elementu konbentzio moduan katalogatu zituzten, elementu horien rola edo funtzioa azaldu nahian, baina baita, konbentzio horiek ebaluatzeko edota beste batzuengatik ordezkatzeko iradokiz. Gauzak horrela, sofistek tradizioa aztertu zutela esan daiteke. Besteak beste, mitoak, erlijioa, balio-sistemak, legeak eta beste hainbat elementu arrazoiaren lupapean ebaluatu zituzten. Hain zuzen ere, mugimendu sofistikoa lehenengo ilustrazio gisa ere da ezaguna, konbentzio ezberdinak arrazoiaren epaimahaitik pasarazten zituelako, horiek ulertu, aldatu, zuzendu edo arrazionalizatzearren. Gainera, konbentzioa gizakiaren produktu den heinean, gizakia zen sofistikaren aztergai nagusienetako bat, arestian aipatu den moduan.

Hainbat giza konbentzioen ebaluaziorekin batera, sofistek jakintza tradizionala kolokan jarri zuten. Hau da, tradizioa konbentzionala dela agerian utzi zuten. Gauzak erlatiboak direnez, elementu oro jarri daiteke zalantzan eta horren inguruko diskurtso ezberdinak sortu daitezke. Horrela, besteak beste, greziarren bi hezitzaile nagusiak ziren Homero eta Hesiodoren irakaspenak aztertu eta, batzuetan, ezbaian ipini zituzten. Are gehiago, orokorrean, greziar mito-sistemaren gaineko analisiak eta iruzkinak sortu zituzten. Era horretan, poesia eta tradizioaren lehenetariko literatura-kritikak sofisten eskutik heldu zaizkigu ${ }^{15}$. Sofistek mito ezberdinen inguruko

15 Dena den, sofisten aurretik dagoeneko rapsodek eurek transmititutako poemen inguruko iruzkinak eta kritikak eskaintzen omen zituzten. Are gehiago, Kolofoneko Xenofanesek tradizio homerikoari kritika latza zuzendu zion sofisten garaia baino lehenago. Halaber, azken horrekin lehian aritutako Regioko Teagenesek Homeroren lehenetariko interpretazio alegorikoa burutu ei zuen. Hortaz, sofistak ekimen horretan berritzaileak izan baziren ere, ez ziren lehenak izan bide hori jorratzen (ik. Svenbro, 1976; Pòrtulas, 2008). 
gogoetak eta interpretazioak egin zituzten. Kontu hori, askotan, mitotik lógosera doan bilakaeraren barnean aipatu ohi da Bigarren Hezkuntzako irakaskuntzan.

Are gehiago, sofistek erlijioaren gaineko hausnarketa aurrera eraman zuten, fenomeno horren funtzioa eta esanahi soziala argitu nahirik. Sofista batzuek erlijioa gizakiaren sorkuntza edo produktutzat ulertu zuten eta horren kausa eta helburuen inguruan hausnarketa ezberdinak eskaini zituzten. Gainera, ez ziren erlijio greziarra hausnartzera mugatzen, baizik eta, era orokorragoan, fenomeno erlijiosoa bere orokortasunean.

Era berean, berebiziko garrantzia izan zuen sofistek burututako eztabaida politikoa; legearen konbentzionaltasuna oinarri edukita, konstituzio ezberdinak aztertu eta sistema politiko eta lege hoberenen inguruko saiakerak sortu zituzten. Sistema politikoa konbentzionala izanik, hau da, gizakiak bere neurrira eraikitzen duela kontuan izanda, sistema hori eraldatzen saiatu ziren, batzuek naturaren izenean, beste batzuek arrazoiarenean. Izanak izan, esanguratsua da kontuan hartzea sofisten artean joera politiko oso bestelakoak egon zirela.

\section{MUGIMENDU SOFISTIKOAK LANDUTAKO HAINBAT GAI FILOSOFIA IKASGAIAN TXERTATZEKO IDEIA- ETA TESTUINGURU- SORTA}

Behin curriculum dekretuak finkatzen dituen gaitasun eta helburuak nabarmenduta eta sofistak nor izan ziren aurkeztuta, lan honen azken erronka hauxe da: mugimendu sofistikoaren azalpen historikoaren bidez eta euren metodo eta gai batzuei heldurik, Batxilergoko dekretuak zehazten dituen hainbat helburu nola bete daitezkeen argitzea. Horrekin batera, testu jakin batzuei egingo diegu erreferentzia, unitate didaktikoak prestatzeko lagungarriak izango baitira.

\subsection{Sofistikaren azalpen historikoa}

Besteak beste, testu honen asmoa da Batxilergoan ikasleen pentsamendua eta hizkuntza maila garatzera bideratuta dauden unitate didaktikoak sortzeko materiala eskaintzea. Horretarako, mugimendu sofistikoaren gaiak oso egokiak direla aldarrikatu nahi da, hizkuntzaren eta argudiatzearen gainean arreta berezia paratzen dutelako eta gizarte mailan ahalmen diskurtsiboek zer nolako garrantzia duten agerian uzten dutelako. Gainera, curriculum dekretuak mito eta lógosaren prozesua aztertu behar dela finkatzen duenez, eta horrez gain, filosofiak Grezian izandako hastapenak ere landu behar direnez, sofisten aurkezpen historikoa egiteak zentzu osoa luke. Hots, oro har, joniar filosofo fisikoen pasarteak aztertuz bete ohi dira 
Filosofia ikasgaiko lehenengo eduki-multzoak. Ezbairik gabe, hori aproposa izan daiteke, baina sofistikaren gaiak ere lotura zuzena du prozesu horrekin, izan ere, aipatu den moduan, sofistak ezagunak izan ziren mitoen inguruko iruzkin eta interpretazioak - horietako asko iruzkin arrazionalizatzaileak - egiteagatik. Era berean, Sokratesen eta Platonen filosofien muina ulertzeko eta euren filosofia zein neurritan berritzailea den eta zein neurritan jarraitutasuna dakarren ikuste aldera, ilustrazio greziarraren nondik norakoa ezagutzea arras interesgarria izan daiteke.

Aurkezpen historikoa prestatzeko, irakaslea azkeneko hamarkadetan sortu izan den material oparoez balia daiteke; esate baterako, Alegre (1986), Bonazzi (2010), Guthrie (1971), Herrick (2005), Kennedy (2011), Kerferd (1981), Murphy, Katula, Hill \& Ochs (2003), de Romilly (1988) eta Lasks \& Most (2016) autoreen lanez. Horrekin batera, erretorikaren bilakaera aztertzeko eta sofistek landutako gaiak egungo testuinguruan nola erabil daitezken ikusteko, interes handikoa da Perelman eta Olbrechts-Tyteca (1958) belgikarren maisulana, zeinean erretorika berri baten inguruan mintzo baitzaizkigu. Erretorikaren gaia ikuspegi garaikideago batetik lantzeko, aipatu berri dugun testuaz gain, Garzia Garmendia (2008) irakaslearen lana gomendagarria da $\mathrm{oso}^{16}$.

\subsection{Logika eta erretorika}

Behin erretorika-maisuak izan zirenen aurkezpen historikoa eginda, hizkuntza eta pentsamenduaren arau nagusiak lantzea oso aproposa izan daiteke. Lehenik eta behin, irakasleak oinarri logiko gutxi batzuk irakatsiko lituzke, hirugarrena baztertzearen printzipioa eta kontraesanik ezaren printzipioan arreta handia jarriz. Horren ostean, estruktura logiko eta argudio forma batzuen berri eman lezake, hala nola, silogismo eta entimemaren berri. Kontu horien inguruko materiala Aristotelesen lanetan aurki daiteke; bere Erretorika eta Organoa dira, ziur aski, horretarako testurik aproposenak eta Organoari dagokionez, bereziki interesgarriak dira Topikoak eta Analitiko Lehenak. Horretaz gain, logika garaikidea edo formala ere kontuan hartzeko, komenigarria litzateke logika testulibururen bat erabiltzea (v. gr. Badesa, Jané \& Jansana, 1998; Deaño 1999).

Behin hori egindakoan, interesgarria izango litzateke ikasleei ariketa praktikoak proposatzea. Esate baterako, silogismoak eta entimemak eraikitzen eskatzea edota silogismo edo entimemaz osatzen diren testuak banatu eta ikasleei eskatzea silogismoak eta entimemak zeintzuk diren identifika-

16 Aurkezpen historikoaren inguruan ez naiz gehiago luzatuko, izan ere, dagoeneko gai horren gainean aritu naiz eta jadanik mugimendu sofistikoaren agerraldiak suposatu zuen hainbat berrikuntza eta paradigma-aldaketen gainean jardun naiz. 
tzea, horien artean ematen diren desberdintasunak argituz. Horretaz gain, lehen aipatutako printzipio logiko nagusiak betetzen dituzten eta betetzen ez dituzten adibideak eskaini ahal ditu irakasleak, ikasleek testuen zuzentasuna edo zuzentasun-eza identifikatu eta azal dezaten. Adibideen artean, irakasleak hainbat poesia-testu erabil ditzake, zeinetan pentsamenduak eta hizkuntzak logika zientifiko edo teknikoa jarraitzen ez baitute. Horren harira, irakasleak komunikazio ekintzetan existitzen diren testuinguru eta erregistro ezberdinen inguruan hitz egiteko abagunea izango luke, poesian, zientzian eta biltzarretan, sarri, logika diskurtsiboa ez darabilgula nabarmenduz.

Modu horretako ariketak diskurtsibitatea lantzeko aproposak lirateke. Gainera, estruktura logikoak euren kabuz identifikatu eta sortu beharko dituzten heinean, ikasleen lan autonomoa sustatuko da. Edonola ere, hainbat ariketa taldeka egin ahalko lirateke, talde-lana ere sustatzeko eta elkarrekin ikasteko konpetentzia lantzeko. Garrantzitsua da baita ikasleek euren artean zuzenketak egiteko gaitasuna bereganatzea.

Behin lehen urrats horiek emanda, ikaslea gai izan beharko litzateke sofistikarekin erlazioa duten testu batzuekin eta sofistek sortutako hainbat testurekin zuzenean harremanean jartzeko. Material horri esker, sofistikaren testuinguru historikoa errepasatzeaz gain, sofistek hizkuntza kontuetan azaltzen zuten maisutasuna eta horrek eragindako hainbat arazo sozial ikusteko beta izango luke ikasleak. Hain zuzen ere, kontu horiek guztiak lantzeko bada Sexto Enpirikoren (ik. Adversus mathematicos, II, 97-99) testu itzel bat, zeinean arestian aipatu ditugun Korax eta Tisiasen gaineko anekdota baten berri ematen baitzaigu. Anekdota umorez beteta dago. Behinola, Koraxek Tisiasi eskatu omen zion erretorika irakasteagatik bere zerbitzuak ordaindu behar zizkiola. Alabaina, Tisiasek ez zion ordaindu nahi eta lehenengoak bigarrena salatu eta epaitegira eraman zuen. Lehengoak hurrengo argudioa erabili omen zuen: «auzia nik irabaziko banu, Tisiasek ordaindu beharko lidake; ordea, galduko banu, horrek begien bistakoa eginen luke Tisiasi ahalmen erretorikoa ongi irakatsi diodala eta, hortaz, era berean, ordaindu beharko lidake». Bigarrenak, aldiz, horrela erantzun ei zuen: «nik irabaziko banu auzia, Koraxi ez nioke ezer ordaindu beharko; ordea, galduko banu, horrek agerian utziko luke Koraxek ez didala ahalmen erretorikoa ganoraz irakatsi eta, hortaz, ez niokeela ezer ordaindu beharko». Sexto Enpirikoren testuak bi sofista aurkezten ditu ohiko testuinguru erretoriko batean, hots, epaitegi baten aurrean. Gainera, hain dira hizkuntzan eta argudiatzean trebeak biak, ezen euren defentsa eta akusazioak arazo bat sortzen duen. Epaileak aporia baten aurrean ipintzen ditu solasaldiak, izan ere, bien argudioek balekoak ematen dute; haatik, ez da posible biek arrazoi edukitzea. Hortaz, testuak arazo politiko bat aurkezten digu, nahiz eta era komiko edo barregarrian.

Sexto Enpirikoren testuan, epaileek bi erretorika-maisuak hiritik kanporatzen dituzte, aporia konpondu baino, deuseztatuz. Sinboloa hurrengoa 
izango litzateke: hiriak, nolabait, sofistengandik defendatzeko beharra du eta, horregatik, euren argudioei jaramon egin gabe deserritu egiten ditu. Gauzak horrela, testu horren bidez curriculumeko Elkarbizitzarako konpetentzia eta Izaten ikasi konpetentzia landu daitezke, gizartean bizitzeak zer suposatzen duen azalduz eta elkarbizitzarako gutxieneko printzipioen inguruan hausnarketa eginez ${ }^{17}$. Nolanahi ere, herritartasunarekin eta politikarekin egin daitezkeen ariketez gain, testua oso aproposa da ikasleei eskatzeko Korax eta Tisiasen argudiatzearen inguruan hausnartzeko eta euren tesien zuzentasuna edo zuzentasun-ezaren inguruan aritzeko. Ikasleei, besteak beste, hurrengoa galdetu ahal zaie: Nolako argudiok erabiltzen dituzte? Bien argudiatzea eta logika zuzenak badira, zergatik sortzen da arazo edo aporia praktiko bat? Era berean, ikasleei eskatu ahal zaie epaileen rola hartzea eta auziari konponbide bat ematen saiatzea. Horretarako, lehenenik bakarka gogoeta egin dezakete eta, ostean, talde txikitan eztabaidatu.

Klasean lantzeko oso interesgarria den beste testu bat Gorgiaren Helenaren goraipamena (Laks \& Most, 2016, fr. 32. Gorg. D24 = fr. DK82B11) dugu. Jakina denez, Helenaren pertsonaia mitologikoak ospe txarra zuen, bere senarrari iruzur egin eta atzerritar batekin ospa egiten omen zuelako. Sofistek, erretorika-maisuak ziren heinean, argudiatzearen bidez iritzi bat aldatzeko zuten gaitasuna erakustea atsegin zuten. Hori testuinguru ezberdinetan egin zezaketen. Hala nola, epaitegian zegoen auzi baten testuinguruan, hitzaldi trebe batek epaileen iritzia aldaraz zezakeen. Helenaren erreferentzia hartuta, eta aipatu berri dugun testuaren bidez, Gorgiak emakume horren ospe txarra zuritu nahi izan zuen, berari zitalkeriak egozten zizkiotenei agerian uzteko, egia esan, emakumeak ez zuela ezer txarrik egin, izan ere, inolako erantzukizunik ez zuelako izan gertatutakoan. Helenaren goraipamena izenburuko hitzaldi laburrak Leontinoko sofistak sortu zuen maisulanetako bat dugu eta, bertan, dotorezia apartaz, Helenaren errugabetasunaren kausak aipatu eta azaltzen zaizkigu. Esanguratsua da nabarmentzea Gorgiak diskurtsoaren pertsuasioa aipatu zuela kausa horien artean, agerian utziz diskurtsoan trebea den norbaitek zer nolako boterea duen. Are gehiago, ondokoa esan zuen Gorgiak diskurtso horretan hitzaren (lógos) inguruan: «hitza subirano boteretsua da, zeinak bere gorputz arrunt arin eta ia ikusiezinarekin aparteko efektuak sortu ahal baitituen; beldurra deuseztatzeko gai da, oinazea ezaba dezake, bizipoza sortarazteko ahalmena badu eta errukia handitzeko gaitasuna». Nolabait, bere diskurtso erretorikoan Gorgiak hizkuntzaren ahalmen erretorikoa goraipatu

17 Testua, hortaz, logika eta erretorikaren gaiak lantzeko aproposa izateaz gain, herritartasuna eta bizikidetza bezalako konpetentziak garatzeko aproposa izan daiteke. Aberastasun hori, ordea, ez da testu horren ezaugarri berezia. Sofisten testuek zeresan handia dute herritartasunari, politikari, hezkuntzari eta hamaika gairi dagokionean. Beraz, hemen aurkezten diren testuak era oso bestelakoan erabil litzake irakasle batek, unean une lantzen dituen helburu didaktikoen arabera. 
zuen. Kontua ez da harritzekoa, izan ere, ideia horri esker jasotzen zutelako sofistek euren soldata.

Ariketa hori garatzerakoan, irakasleak lehenik eta behin Helena pertsonaia mitologikoaren inguruko kondairak aipa litzake, oro har, Helenak greziarren artean ospe txarra zeukala nabarmenduz ${ }^{18}$. Jarraian, Helenaren goraipamena testua klasean bana lezake, sofista zehatz batek argudioen bidez iritzi bat aldatzeko egin zuen saiakeratzat aurkeztuz. Testu horri esker, ikasleek argudiatze erretorikoaren eredu itzel bat ikusteko aukera izango lukete eta, eredua aztertu ostean, irakasleak hainbat ariketa proposa litzake horren harira. Hala nola, eskatu ahal zaie Gorgiari kontra egiten dion argudio edo argudio-multzo bat asmatu eta idaztea; era berean, eskatu ahal zaie testua eredutzat harturik, pertsonaia garaikide eta ospe txarra duen baten inguruko goraipamen, laudorio edo defentsa egitea, bere izen onaren alde egiteko eta jendearen iritzia aldatzeko ${ }^{19}$.

Era berean, erretorikaren gaia lantzeko anitz interesgarria izan daiteke Seneka Zaharra latinoaren Kontrobersien adibideak klasean ikustea eta ikasleei eskatzea halako defentsak edo akusazioak sor ditzaten. Are gehiago, taldea hirukoteka banatuta, proposatu ahal zaie epaitegi baten testuingurua irudikatzeko: ikasle batek epailearen rola hartuko luke, beste batek akusazioarena eta hirugarren batek, aldiz, defentsarena. Ikasleei euren rola prestatzeko denbora eskaini behar zaie eta, gero, klase aurrean, epaiketa bera antzeztu beharko lukete. Modu berean, erretorika lantzeko batbateko epaiketa modukoak sor daitezke, bat-bateko argudiatze-konpetentzia lantzeko.

Kontuan izan behar da komunikazio ekintzak lantzen diren heinean, zeinetan dialogo eta eztabaidaren premia baitagoen, curriculumak zehazten dituen konpetentziak jorratzen direla eta Filosofia ikasgaiari esleitzen zaizkion helburu nagusietako bat - hots, komunitate ikuspegia lantzeagaratzen dela, izan ere, dialogoaren eta elkarrekintzaren bidez bultzatzen da komunitate politiko parte-hartzailea. Hori helburu nagusi gisa edukita, klasean komunikazio testuinguru desberdinak sortu eta ikasleak horietan trebatze aldera, interesgarria litzateke oso irakasleak Joxerra Garziaren (2008) Komunikazio gaitasuna lantzeko eskuliburua baliatzea. Testuak erretorikaren gai zaharra puri-purian dagoela frogatzeaz gain, gure egongo hamaika komunikazio egoerei modu arrakastatsuan aurre egiteko metodo-

18 Hori egite aldera, irakasleak Grimalen (1951) hiztegiaz balia dezake.

19 Halaber, nahiz eta logika eta erretorikaren gaien lanketaren esparruko ariketak ez izan, posible litzateke hizkuntzaren indarrak gizartean eta politikan duen eragina aztertzea, hala nola, adierazpen askatasuna erabatekoa izan behar lukeen planteatuz; ariketa posible bat izango litzateke klasea taldeka banatzea eta talde horietan batzuek erabateko adierazpen askatasuna defenda lezaten eta beste batzuek, aldiz, askatasun horri mugak ipintzearen komenigarritasuna. Halako jarduerek herritartasuna lantzeko balioko lukete eta elkarbizitzarako konpetentzia bete-betean jorratuko lukete. 
logia bat eskaintzen du, gazte zein helduoi oso mesedegarria suerta dakigukeena. Irakasleak prozedura horien eskema orokor bat sor lezake eta euren ikasleei eskatu balizko komunikazio testuinguru ezberdinetan praktikan ipintzea.

\subsection{Subjektua eta erlatibismo epistemologiko eta morala}

Curriculumak zehazten duenaren arabera, subjektua, erlatibismo morala eta ekintza moralaren oinarriak landu beharreko kontuak ditugu. Sofisten bidez hori lantzea posible da. Esate baterako, gaiok aurkezteko Protagorasen homo-mensura teoria laburbiltzen duen esaldi famatua aurkeztu eta aztertu daiteke: «Gizakia gauza guztien neurria da; direnak diren heinean eta ez direnak ez diren heinean» (Laks \& Most, 2016, fr. 31. Prot. D9 = fr. DK80B1). Irakasleak esaldia aurkeztearekin batera, horren interpretazio ezberdinen berri eman beharko luke, hala nola, Cassin (1995), Kerferd (1981) eta de Romilly (1988) helenisten proposamenak aurkeztuz. Abagune horretaz baliatuz, sofistikak subjektuari eskaini zion garrantziaz jardun ahalko du irakasleak, bide batez, subjektibismo, perspektibismo eta erlatibismo epistemologikoaren inguruan hausnartuz.

Erlatibismo epistemologikoa testu baten bidez azaldu nahi balitz, Gorgiaren Ez-izateaz diskurtsoa klasean banatzea posible litzateke. Irakasleak horren gaineko iruzkin bat egin lezake ${ }^{20}$, ikasleei galderak eginez eta berak erantzunak, nolabait, bideratuz.

Behin subjektua eta erlatibismo epistemologikoen gaiak azalduta, irakasleak era errazean ondoriozta dezake sofisten erlatibismo epistemologikoak erlatibismo morala susta dezakeela. Hori ikuste aldera, Aristofanesen Hodeiak komediaren berri eman lezake irakasleak, zeinean sofistika eta, oro har, irakaskuntza berritzailea zabaltzen dutenen aurkako kritika gogorra ikus baitaiteke. Komedia hori oso entretenigarria da eta etxerako lan moduan horren irakurketa eta iruzkina eskatuta, ikasleen interesa sustatzea posible litzateke. Edonola ere, kontuan hartu beharra dago hori horrela izateko eta ikasleei irakurketa zailegia gerta ez dakien, beharrezkoa litzatekeela irakasleak aldez aurretik obraren nondik norakoa klasean azaltzea eta bertan irudikatzen diren sofisten eta Sokratesen inguruko hainbat kontu argitzea.

Horren ostean, irakasleak erlatibismo moralaren inguruan eztabaida taldeak antolatu litzake. Talde txikitan ikasleek erlatibismo moralaren gainean duten iritzia azaldu beharko lukete ${ }^{21}$. Ostean, irakaslea erroko edo

\footnotetext{
${ }^{20}$ Iruzkin hori prestatzeko Bredlow (2016) irakaslearen lana gomendagarria da oso.

${ }^{21}$ Erlatibismo morala aurkezteko orduan, Dissoì lógoi izenez ezagutzen den testua oso material baliagarria izan daiteke.
} 
muturreko erlatibismo moralak eduki ditzakeen arazo eta arriskuen inguruan aritu liteke, eta, horrela, iritzi ezberdinak bideratu. Halaber, interesgarria izango litzateke klasea bi taldetan banatzea eta klase erdiari erlatibismo moralaren laudorio bat egitea eskatzea eta beste erdiari, aldiz, horren aurkako kritika bat. Horrekin, komunitatearen zentzua eta giza balio funtsezko batzuk igortzea bilatuko litzateke, gure gizarteen bizkarrezurra direnak eta gure herritartasun-bertuteak definitzen dituztenak.

Azkenik, ekintza moralaren oinarriak lantzeko asmoz, irakasleak nómos/phýsis eztabaida klasikoa aurkez lezake, erakutsiz sofista batzuek ekintza moralaren oinarria naturan bertan kokatzen zutela eta beste batzuek, aldiz, konbentzioan. Hori irudikatzeko makina bat testu eta adibide erabil daitezke. Esate baterako, ekintza morala naturan oinarritzen duen tesi bat aurkezteko, irakasleak Platonen Gorgia dialogoan Kalikles pertsonaiak darabilen diskurtsoa erabil lezake (ik. Platon, Gorgia, 482e-484c). Aldiz, iritzi horri kontrajarrita, Antifonteren (Laks \& Most, 2016, fr. 37. Antiph. D38 = fr. DK87B44) ikuspegia aurkez lezake.

\subsection{Sofistak, politika eta kontratu soziala}

Sofistek tradizioa ezbaian jarri zuten eta euren garaiko sinesmen, balio eta legeen inguruko hausnarketa gauzatu zuten. Ildo horretatik, sofistek konstituzio ezberdinen inguruko gogoeta egin zuten, eta legea eta bestelako kontu politikoak konbentzionalak direla azaldu. Kontua interesgarria da, bide batez, agerian uzten duelako gaur egungo legeak edo gizakien eskubide unibertsalak jasotzen dituen agiriaren moduko dokumentuak ez direla naturalak — nahiz eta gaur egun oraindik eskubide horiek berezkoak edo jaiotzatikoak direla uste duen jende ugari egon-, konbentzio baten produktua baizik. Zentzu horretan, legeak, eskubideak eta betebeharrak berrikusi eta aldatu daitezkeen elementuak dira, giza komunitate baten mesederako edota bere beharren arabera doitu behar direnak. Gaia, puri-purian dagoena, sofisten eredu historikoaren bidez landu daiteke.

Hainbat sofistek politikarekin harreman estua izan zuten. Adibidez, ezaguna da Periklesek Protagorasekin izan zuen laguntasuna. Antza, Protagoras Turioseko hiri panhelenikoaren konstituzioa sortu zuten pertsonetako bat izan zen. Halako kontuen bidez, irakasleak nabarmendu dezake sofistek politika kontuan eskumen handia izan bide zutela eta Greziako berrikuntza demokratikoarekin harreman estua izan zutela.

Horretaz gain, mugimendu sofistikaren gainekoek politika kontuetan sakontzea posible egiten dute. Hala nola, gaur egun berriz ere garrantzia handia duen teoria bat kontratu sozialena dugu - botere politikoak jendearen babesa edo zilegikotasuna (auctoritas) galtzen duenean, bere burua justifikatzeko premia duelako - eta kontu hori ere sofisten eskutik landu daiteke. Dagoeneko aipatu dudan bibliografiaz gain, irakasleak kontratu 
sozialaren inguruko irakas materiala Kahn (1981) estatubatuarrak idatzi zuen testuaren bidez presta lezake. Autore horren hipotesia da kontratu sozialen lehenengo teoriak Grezian sortu zirela KA v. mendean. Testu horretan bertan irakasleak unitate didaktiko bat prestatzeko material eta aipamen ugari aurki ditzake.

\subsection{Mitoen iruzkingileak eta fenomeno erlijiosoaren ikerlariak}

Sofistek mitoen inguruan egin zituzten saioak testu askoren bidez landu daitezke - kontuan izan aipatu dugun Gorgiaren Helenaren goraipamena ere tradizio mitiko baten gainean egindako ariketa dela-. Esate baterako, Platonen Fedro dialogoan Boreas eta Oritiaren inguruko mitoa azaltzeaz gain, bere gainean egin daitezkeen bi interpretazio alegoriko arrazionalizatzaile aipatzen dira (Platon, Fedro, 229b-230b). Testu labur horren bidez erraza litzateke sofistek burututako saio iruzkintzaile batzuen nondik norakoa aztertzea. Testua klasean irakur daiteke eta antzekoak diren bestelako testuak banatuta, hala nola Esoporen Fabulen bidez, ikasleei eskatu ahal zaie ariketa alegorikoak euren kabuz egitea.

Are eta interesgarriago, sofistekin erlazionatutako testu arrunt erakargarri batek erlijioaren sorreraren eta bere funtzio sozialaren inguruan egindako gogoeta interesgarriak erreproduzitzen dizkigu. Testua bi iturri ezberdinetik heldu zaigu, Sexto Enpiriko (Adversus mathematicos, IX, 54) eta Aezio (I 6,7), alegia. Lehengoak testua Kritiasi egozten dio; bigarrenak, ordea, Euripidesi eta, zehazkiago, Sisifo izenburua zuen tragedia galduari. Hortaz, testuaren autoretza kolokan dago, baina horrek ez du garrantzi handirik, izan ere, testuak sofistikaren pentsamendua eta prozedurak islatzen ditu. Testua laburra, ulerterraza eta oso esanguratsua da. Autoreak suposatzen du jainkoak ez direla naturaz existitzen, gizakion sorkuntza lirateke, hots, konbentzio bat. Hori oinarri, autoreak jainkoen asmakuntzaren balizko kausa eta funtzioaz dihardu: bere aburuz, premia politiko jakin bat asetzeko sortutako konbentzioa dugu. Hirietan ongi definitutako legeak eta zigor-sistema egon arren, hiritarrek horien kontra jokatuko lukete testigantzarik ez dagoen egoeratan, hain zuzen ere, zigortuak izateko beldur ez liratekeelako. Jainkoekiko fedeak, besteak beste, orojakileak diren eta dena ikusten eta zigortu dezaketen izaki batzuen sinesmena eragingo luke jendearengan. Horren ondorioz, jende askok hiriko legeak eta moraltasuna urratzeari utziko lioke, jainkoen zigorren beldurrez.

Irakasleak Kritiasena edo Euripidesena omen zen testua klasean bana lezake, ikasleei irakurtzea eskatu eta, ondoren, iruzkina egin dezaten proposatu. Horren ostean, gure garaian funtzio sozial garrantzitsuak betetzen dituzten mito edo konbentzioak existitzen diren galde lezake, ikasleek horren inguruan hausnar dezaten. Azkenik, ariketa interesgarria izango litzateke horrelako mitoen egokitasunaren edo egokitasun ezaren gaineko ezta- 
baida sustatzea ikasleen artean. Ziur aski, gaiak eztabaida eragingo luke, ikuspegi ezberdinak azaleratuz. Are gehiago, batzuen arabera mitoa dena, beste batzuentzat ez da mitoa izango. Azken finean, posible litzateke baita ere banatu dugun testuari kontra egitea eta berak defendatzen duena mitoa baino ez dela defendatzea.

Ariketa honen bidez, era berean, gaur egun mitoak eta erlijioek duten rol sozialaz eta funtzioaz hitz egitea posible litzateke, sofisten testuingurua eta gurea erkatuz, garaikideak iruditzen zaizkigun hainbat tesi antzinatean dagoeneko aldeztuak izan zirela agerian utziz.

\section{ONDORIOAK}

Lan honen helburu nagusia izan da sofistika eta erretorikaren gaiak Batxilergoko dekretuak zehazten dituen helburu eta konpetentziak lantzeko eta bertan finkatzen diren edukiak emateko erabat aproposak direla erakustea. Horrekin, agerian utzi nahi izan dugu gai hori lantzea oso esanguratsua izan daitekeela, ez bakarrik historikoki mugimendu sofistikoak izandako garrantziarengatik, baizik eta ahalmen diskurtsiboa lantzeko eskaintzen duen aukera paregabeagatik. Gure asmoa bete bada eta greziar ilustrazioaren inguruko informazioa eta testuak Filosofia ikasgaian txertatzea posiblea izateaz gain, ideia ona dela demostratu bada, testu honek erronka berritzaile bat bultzatuko luke, sofistika eta erretorikaren inguruko unitate didaktikoak prestatzea, alegia. Hain zuzen ere, erronka horretarako hainbat ideia eta material proposatu dira. Edozein kasutan, unitate didaktiko horiek modu anitzetan gorpuz daitezke bai eduki zein metodologiari dagokionez. Horregatik, ariketa zehatzak baino, ideia eta materialak eskaini ditugu, irakasle bakoitzak bere interesen arabera molda ditzan.

Halaber, aipatzekoa da sofistikaren gaia jorratzeak jakin-min historikoa asetzeko aukera emateaz gain, gaur eguneko hainbat gai eta kontu zeharka hausnartzea posible egiten duela. Hizkuntzaren osagai erretorikoa betierekoa dela aipatu dugu eta, era berean, sofistek proposatutako hainbat gai eta ikuspegi puri-purian daudela azken aldi honetan. Beraz, antzinako eredu eta kontuak aztertzen, gaur eguneko gizartean arrunt erabilgarria den irakaspena lortzea posible litzateke sofistikaren gaiak eta testuak landuz. Mugimendu sofistikoaren ingurukoak eta erretorika lantzeak sari bikoitza duela esan genezake: alde batetik, jakintza historiko bat eskaintzen du; bestetik, gaurkotasun erabatekoa duen ezagutza praktiko batez hornitzen gaitu. Hain zuzen ere, ez dezagun ahaztu, Batxilergoaren helburua gazteak gaur eguneko testuinguru sozialerako prestatzea da. Hori, ordea, atzera begira erdietsi daiteke, hala nola, sofisten inguruko proposamen didaktiko baten medioz. Behintzat, hori da testu honek aldarrikatzen duena. 


\section{ERREFERENTZIAK}

\section{Batxilergorako eskuliburuak}

Baigorri, G.J.A. (2015). Filosofia, Batxilergoa 1. Bizkaia: Ibaizabal.

Cortina, O.A. (2008). Filosofia eta gizabide hezkuntza 1, Batxilergoa: «Jakintzaren etxea» proiektua. Bizkaia: Zubia.

Cortina, O.A. (2015). Filosofia, Batxilergoa 1. Bizkaia: Santillana-Zubia.

Z.Z.E.E. (2009). Baikor 1, Batxilergoa. Bizkaia: Zubia.

Z.Z.E.E. (2015). Filosofía, 1 Bachillerato. Bartzelona: Edebé.

\section{Curriculum dekretua}

127/2016 Dekretua, irailaren 6koa, Batxilergoko curriculuma zehaztu eta Euskal Autonomia Erkidegoan ezartzekoa. [http://www.hezkuntza.ejgv. euskadi.eus/contenidos/informacion/heziberri_2020/eu_2_proyec/adjuntos/ Dekretua_127_2016_batx_e.pdf].(2017/08/10ean kontsultatua).

127/2016eko Dekretuaren II. Eranskina osatzen duen curriculum orientatzailea. [http://www.hezkuntza.ejgv.euskadi.eus/contenidos/informacion/ heziberri_2020/eu_2_proyec/adjuntos/Batxilergoko_curriculum_osoa.pdf]. (2017/08/10ean kontsultatua).

\section{Erretorika lantzeko eskuliburu garaikideak}

Garzia Garmendia, J. (2008). Jendaurrean hizlari: (Ahozko) Komunikazio gaitasuna lantzeko eskuliburua. Irun: Alberdania.

Perelman, C., \& Olbrechts-Tyteca, L. (1958). La nouvelle rhétorique: Traité de l'argumentation. Paris: Presses universitaires de France.

\section{Logika eskuliburuak}

Badesa, C., Jané, I., \& Jansana, R. (1998). Elementos de lógica formal. Bartzelona: Ariel.

Deaño, A. (1999). Introducción a la lógica formal. Madril: Alianza.

\section{Sofistikaren inguruko lanak}

Alegre Gorri, A. (1986). La sofística y Sócrates: Ascenso y caida de la polis. Bartzelona: Montesinos.

Bonazzi, M. (2010). I sofisti. Erroma: Carocci.

Cassin, B. (1995). L'effet sophistique. Paris: Gallimard.

Cole, T. (1991). The origins of rhetoric in ancient Greece. Baltimore: Johns Hopkins University Press. 
Conley, T.M., \& Polansky, R. (1985). Dating the So-called Dissoi Logoi. Ancient Philosophy, 5 (1), 59-65.

Goux, J.-J. (1999). Edipo filósofo. Buenos Aires: Biblos.

Grimal, P. (1951). Dictionnaire de la mythologie grecque et romaine. Paris: Presses universitaires de France.

Guthrie, W.K.C. (1971). The Sophists. Londres: Cambridge University Press.

Herrick, J.A. (2005). The history and theory of rhetoric: An introduction. Boston: Allyn and Beacon.

Kahn, C.H. (1981). The origins of social contract theory. In G.B. Kerferd (zuz.), The Sophists and their Legacy (92-108 orr.). Wiesbaden: Franz Steiner Verlag GMBH.

Kennedy, G.A. (2011). A New History of Classical Rhetoric. Princeton: Princeton University Press.

Kerferd, G.B. (1981). The sophistic movement. Cambridge: Cambridge University Press.

Marrou, H.I. (1965). Histoire de l'éducation dans l'antiquité. Paris: Éditions du Seuil.

Murphy, J.J., Katula, R.A., Hill, F.I., \& Ochs, D.J. (2003). A synoptic history of classical rhetoric. Mahwah, N.J: Hermagoras Press.

Pòrtulas, J. (2008). Introducció a la Ilíada: Homer, entre la història i la llegenda. Bartzelona: Fundació Bernat Metge.

de Romilly, J. (1988). Les grands sophistes dans l'Athènes de Périclès. Paris: Editions de Fallois.

Rossetti, L. (1982). Tre studi sui Dissoi logoi. Studi Filosofici, 3, 27-54.

Svenbro, J. (1984). La parola e il marmo: Alle origini della poetica greca. Turin: Boringhieri.

\section{Sofisten testuak eta sofisten inguruko antzinako berriak}

Bredlow, L.A. (2016). Gorgias. De lo que no es, o De la naturaleza: los testimonios. Bartzelona. Anthropos.

Laks, A. \& Most, G.W. (2016). Les débuts de la philosophie. Paris: Fayard.

Robinson, T.M. (1979). Contrasting arguments: An edition of the Dissoi logoi. New York: Arno Press.

Solana, D.J. (1996). Protágoras de Abdera. Dissoi Logoi: Textos relativistas. Madril: Akal.

Solana, D.J. (2013). Los sofistas: Testimonios y fragmentos. Madril: Alianza Editorial. 